\title{
Pair-Trawl Detection of PIT-Tagged Juvenile Salmonids Migrating in the Columbia River Estuary, 2008
}

\author{
Robert J. Magie, Matthew S. Morris, Richard D. Ledgerwood, Benjamin P. Sandford, \\ and Gene M. Matthews
}

\author{
Report of research by \\ Fish Ecology Division \\ Northwest Fisheries Science Center \\ National Marine Fisheries Service \\ National Oceanic and Atmospheric Administration \\ 2725 Montlake Boulevard East \\ Seattle, Washington 98112-2097 \\ for \\ Division of Fish and Wildlife \\ Bonneville Power Administration \\ U.S. Department of Energy \\ P.O. Box 3621 \\ Portland, Oregon 97208 \\ Contract 40735 \\ Project 199302900
}

May 2009 


\section{EXECUTIVE SUMMARY}

In 2008, we sampled migrating juvenile Pacific salmonids Oncorhynchus spp. tagged with passive integrated transponder (PIT) tags using a surface pair trawl in the upper Columbia River estuary (rkm 61-83). The cod-end of the trawl was replaced with a cylindrical PIT-tag detection antenna with an 86-cm-diameter fish-passage opening and two detection coils connected in series. The pair trawl was $105 \mathrm{~m}$ long with a 91.5-m opening between the wings and a sample depth of $4.9 \mathrm{~m}$. Also during 2008, we finalized the development of a prototype "matrix" antenna, which was larger than previous antennas by a considerable magnitude. The matrix antenna consisted of 6 coils: a 3-coil front component and a 3-coil rear component, which were separated by $1.5-\mathrm{m}$ of net mesh. The fish-passage opening was $2.5 \mathrm{~m}$ wide by $3.0 \mathrm{~m}$ tall and was attached to a standard-size pair trawl net.

Intermittent sampling with a single crew began on 7 March and targeted yearling Chinook salmon O. tshawytscha and steelhead O. mykiss. Daily sampling using two crews began on 30 April and continued through 14 June; during this period we detected 2.7\% of all juvenile salmonids previously detected at Bonneville Dam-a measure of sample efficiency. Sampling with a single crew continued through 20 August and targeted subyearling Chinook salmon. We detected 7,397 yearling Chinook salmon, 2,735 subyearling Chinook salmon, 291 coho salmon O. kisutch, 5,950 steelhead, and 122 sockeye salmon $O$. nerka in the upper estuary.

We deployed the matrix antenna system and the older, cylindrical antenna system (86-cm-diameter fish-passage opening) simultaneously in mid-May 2008 to test matrix detection efficiency. The cylindrical antenna system had been used successfully in 2007 and early 2008. Because distribution of migrating salmonids in the estuary changes rapidly, we felt that a tandem sampling effort between the two systems was the only way to truly evaluate comparative detection efficiency. We deployed both systems within $1 \mathrm{~km}$ of each other during a period of high fish densities on 13, 14, and 15 May.

Detections of the matrix system surpassed those of the cylindrical system by $53 \%$ in $14 \mathrm{~h}$ of simultaneous sampling (total detections 716 and 339, respectively). We believe that the higher detection rate observed with the matrix system was due to fewer smolts escaping the trawl entrance and to more smolts readily passing through the larger fish-passage opening. After tandem sampling, we continued exclusive use of the matrix system for the remainder of the 2008 juvenile migration season.

Mean survival rates from Lower Granite to Bonneville Dam for yearling Chinook salmon and steelhead were $42 \%(\mathrm{SE}=3.7 \%)$ and $46 \%(\mathrm{SE}=1.5 \%)$, respectively. Over 358,000 PIT-tagged salmonids were transported, and we detected 4,619 of these fish. 


\section{CONTENTS}

EXECUTIVE SUMMARY ...............................................................................

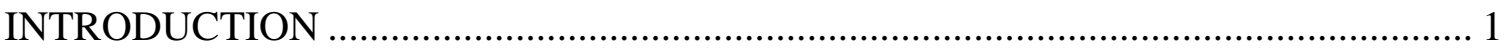

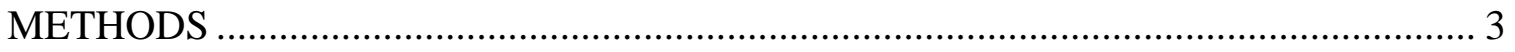

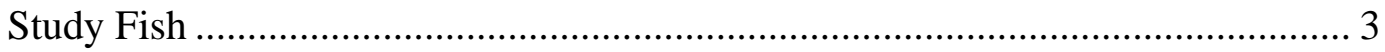

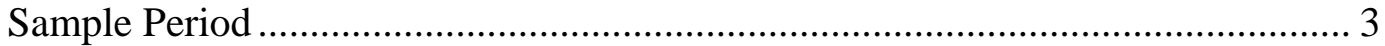

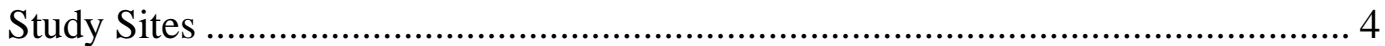

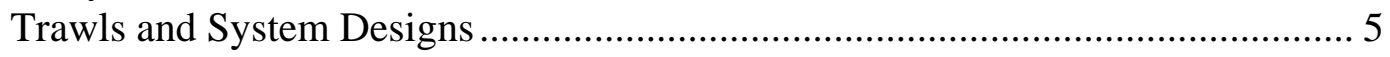

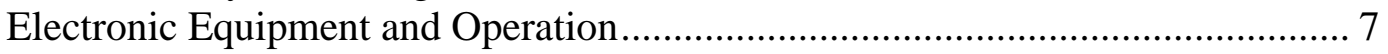

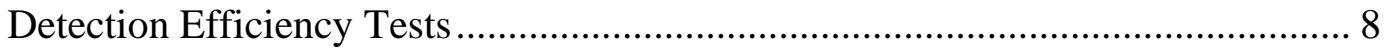

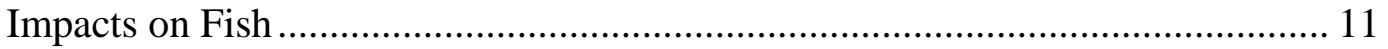

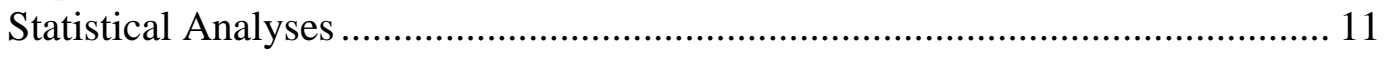

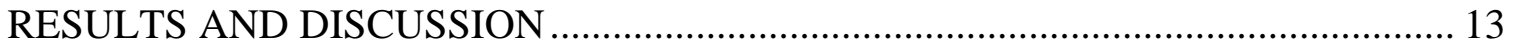

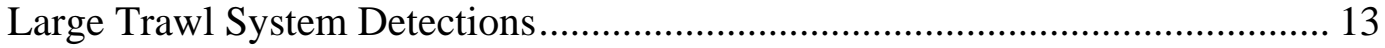

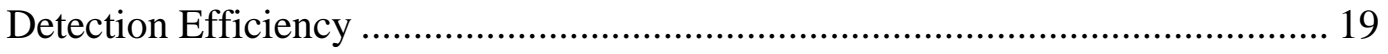

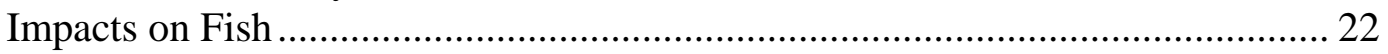

Sampled PIT-Tagged Fish ............................................................................... 23

Survival Estimates of In-river Migrants to the Tailrace of Bonneville Dam........ 25

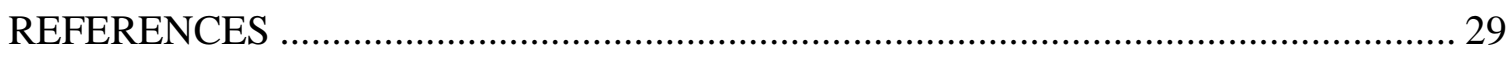

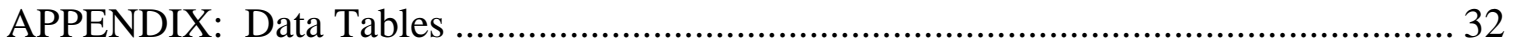




\section{INTRODUCTION}

In 2008, we continued a multi-year study of survival and migration timing for juvenile Pacific salmonid Oncorhynchus spp. in the Columbia River estuary (Ledgerwood et al. 2006, 2007; Magie et al. 2008). This study was funded by the Bonneville Power Administration (BPA) and U.S. Army Corps of Engineers (USACE). Here we report on survival and timing of fish related to river of origin and migration history, which are specific objectives supported through BPA. Moreover, the BPA-funded portion of this study is a companion to an additional BPA study to estimate survival of juvenile salmonids through the entire Federal Columbia River Power System (FCRPS) from the reservoir of Lower Granite Dam on the Snake River to the tailrace of Bonneville Dam on the Columbia River (Faulkner et al. 2009).

Detections of migrating fish implanted with passive integrated transponder (PIT) tags were utilized by both BPA-funded studies. PIT tags are generally implanted in juvenile salmonids captured in natal streams, hatcheries, or collector dams prior to or during migration (PSMFC 2008). Once tagged, these fish can be interrogated without further handling as they pass through detection antennas during their seaward migration. PIT-tag detection systems are presently located in the bypass systems at dams (Prentice et al. 1990a,b,c), in some natal streams and side-channel areas, and in our pair trawl. The Columbia Basin PIT tag Information System (PTAGIS) is a regional database used to store and disseminate tagging and detection data. We recorded and uploaded all data collected with the trawl to PTAGIS, including detection times and locations. We downloaded from PTAGIS the associated release and migration information for fish detected with the trawl, including species, origin, and migration history of individual PIT-tagged fish.

Methods for using PIT-tag detection data to estimate survival and travel time for juvenile salmonids migrating during spring 2008 are described in detail by Faulkner et al. (2009). Briefly, PIT-tag data were automatically uploaded to PTAGIS from interrogation facilities at Lower Granite, Little Goose, Lower Monumental, and Ice Harbor Dams on the Snake River and at McNary, John Day, and Bonneville Dams on the Columbia River. Survival estimates were calculated using a statistical model for tag-recapture data from single-release groups.

To extend the reach survival estimates to Bonneville Dam, the lowermost dam in the FCRPS at rkm 234, requires sampling of PIT-tagged fish downstream from the dam. In this report we describe the methodology for sampling PIT-tagged fish in the upper estuary between river kilometers ( $\mathrm{rkm}$ ) 61 and 83. We interrogated tags using surface pair-trawls fitted with specialized detection equipment in a free-flowing riverine 
environment (Ledgerwood et al. 2004). These samples provided data to estimate reach survival from the tailrace of John Day Dam (rkm 347) to the tailrace of Bonneville Dam and also contributed substantial data required to complete the reach survival estimates from McNary (rkm 470) to Bonneville Dam.

Nearly 2.4 million PIT-tagged juvenile salmonids were released into the Snake and Columbia River basins for migration in 2008 (PSMFC 2008). In addition to bypassing fish at dams, fishery managers have the option to transport and release fish downstream from Bonneville Dam. In 2008, over 358,000 PIT-tagged fish were transported. The primary goals of our trawling effort in the estuary were to provide data to estimate survival probabilities of PIT-tagged fish that have migrated through the hydropower system to the estuary (BPA objective) and to compare relative survival and temporal differences between transported and inriver migrants previously detected at Bonneville Dam (USACE objective). Another goal was to increase sample efficiency by continuing to test and sample intermittently using new antennas with larger fish-passage openings. We termed this prototype system the "matrix" system, as it consisted of a multiplexing transceiver which controlled from 5 to eventually 6 antenna coils configured to provide a 2.6-m wide by 3.0-m tall fish passage opening from the trawl. 


\section{METHODS}

\section{Study Fish}

In 2008, we continued to focus research on large groups of PIT-tagged fish migrating through the upper Columbia River estuary (rkm 75) from late April through late June. Due to the increased tagging of subyearling fall Chinook salmon released later in the migration season, we extended sampling into July and August. According to PTAGIS, these groups included over 136,876 PIT-tagged fish released for a transportation study on the Snake River (Marsh et al. 2006) and nearly 216,982 PIT-tagged fish released for a comparative survival study (Berggren et al. 2006). Fish from other major and minor PIT-tagging studies were detected as well.

During the spring migration, we targeted yearling migrants, including approximately 600,000 yearling Chinook salmon, over 800,000 subyearling fall Chinook salmon, and over 480,000 steelhead that had been PIT-tagged and released into the Snake and upper and mid-Columbia Rivers. These fish were either allowed to migrate in the rivers to the estuary or were collected and transported past up to 8 dams and reservoirs from the Snake River basin. Transported fish were collected from facilities at Lower Granite, Little Goose, Lower Monumental and McNary Dams and released downstream from Bonneville Dam.

In addition to the Snake River transportation study, several other studies in the Columbia River basin released large numbers of spring-migrating, PIT-tagged juvenile salmonids. In this report, we focus analyses on the more numerous PIT-tagged yearling Chinook salmon and steelhead; however, detections of PIT-tagged coho salmon O. kisutch, sockeye salmon O. nerka, and subyearling Chinook salmon were also recorded.

\section{Sample Periods}

Daily sampling began in late April and ended in late June, coincident with the passage of PIT-tagged yearling Chinook salmon and steelhead from the Snake River transportation study. Sampling with the cylindrical system began in March, and ended in mid-May, after satisfactory in-water tests of the matrix detection system. After 15 May the matrix trawl system was used exclusively for sampling. Beginning on 30 April and extending through 14 June, sampling increased from a single daily sampling crew to two

daily crews for an average of $12 \mathrm{~h} \mathrm{~d}^{-1}$. Generally, the day crew began before daylight and sampled for 8 to $10 \mathrm{~h}$, and the night crew began in late afternoon and sampled until well after dark or until relieved by the day crew. 
Intermittent daily sampling with a single crew continued from mid-June into late August and again from September through October, targeting sub-yearling fall Chinook salmon.

\section{Study Sites}

We conducted trawl operations at the entrance to the estuary from approximately Eagle Cliff (rkm 83) downstream to the west end of Puget Island (rkm 61; Figure 1). This is a freshwater reach characterized by frequent ship traffic, occasional severe weather, and river currents often exceeding $1.5 \mathrm{~m}^{3} \mathrm{~s}^{-1}$. Tides in this area are semidiurnal, with about $7 \mathrm{~h}$ of ebb and $4.5 \mathrm{~h}$ of flood. During the spring freshet periods (April-June), little or no flow reversal occurs at the study site during flood tides, particularly during years of medium-to-high river flow. The net was deployed adjacent to a 200-m-wide navigation channel, which is maintained at a depth of $14 \mathrm{~m}$.

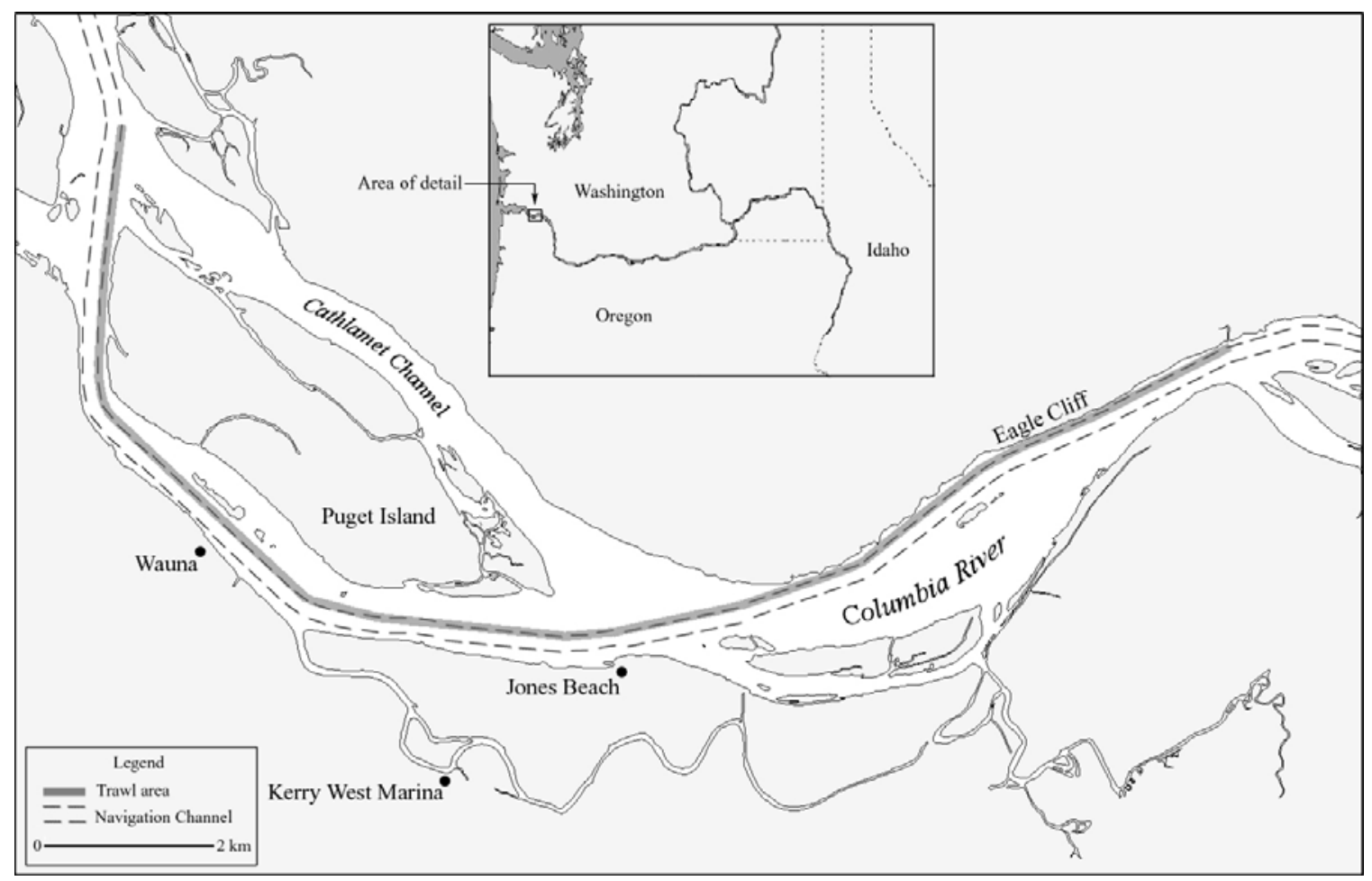

Figure 1. Trawling area adjacent to the ship navigation channel in the upper Columbia River estuary near rkm 75. 


\section{Trawls and System Designs}

The large trawl components are described below, and their basic configuration has remained fairly constant throughout the study period (Ledgerwood et al. 2004; Figure 2). To prevent turbulence on the net from the tow vessels, 73-m-long tow lines were used. The upstream end of each wing of the trawl initiated with a 3-m-long spreader bar, which was shackled to the wing section. The end of each wing was attached to the 14-m-long trawl body followed by a 2.7-m-long cod-end, modified for antenna attachment. The mouth of the trawl body opened between the wings and from the surface to a depth of $6 \mathrm{~m}$; a floor extended $9 \mathrm{~m}$ forward from the mouth.

The cylindrical detection antenna system was $2.1 \mathrm{~m}$ long, $0.9 \mathrm{~m}$ in diameter, and weighed $200 \mathrm{~kg}$. When deployed, the antenna was suspended on a buoy centered at a depth of $1.8 \mathrm{~m}$. Tag technology has improved over the years, enabling us to enlarge the fish-passage opening, which reduced drag and lift on the net. This increased the sample depth of the trawl from $4.3 \mathrm{~m}$ in 1995-1999 to $4.6 \mathrm{~m}$ in 2000-2007. During a typical deployment of the trawl/antenna configuration, the net was towed upstream, facing into the current.

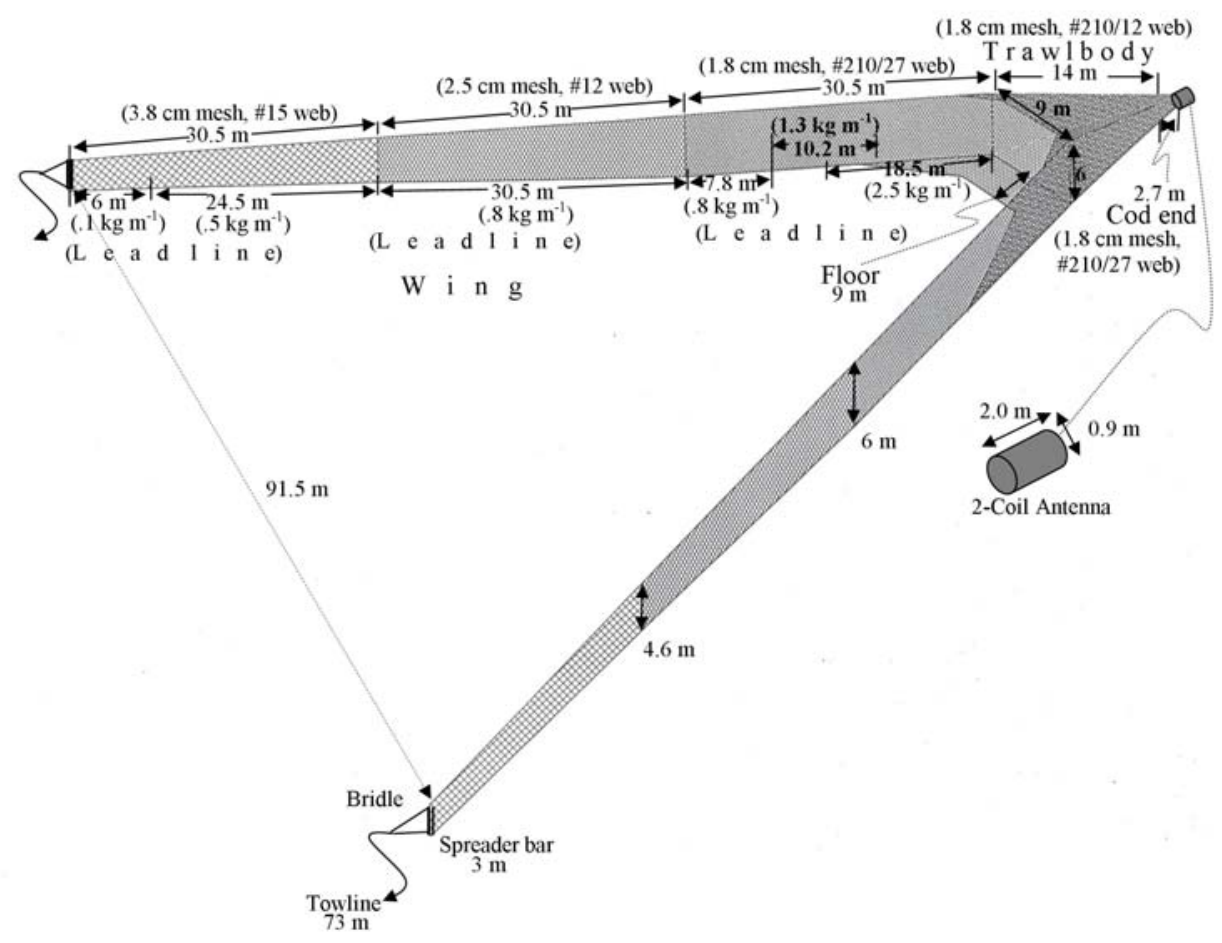

Figure 2. Design of the surface pair-trawl and cylindrical, two-coil antenna system used to sample PIT-tagged juvenile salmonids in the Columbia River estuary (rkm 75). 
Under tow we maintained a distance of $91.5 \mathrm{~m}$ between the wings of the trawl, which resulted in an effective sample depth of $4.6 \mathrm{~m}$ (measured at the center of the floor lead line). Fish that enter between the wings are guided to the trawl body and exit through the antenna. During retrievals of the net, the cylindrical antenna unit was removed to the barge and the net inverted in the current to flush debris and release fish from between the small-mesh wings. This deployment/retrieval process of the cylindrical trawl required about $30 \mathrm{~min}$, during which time the vessels and net are adrift in tidal and river currents often exceeding $1.5 \mathrm{~m} \mathrm{~s}^{-1}$ (3 knots).

The matrix trawl system (Figure 3) incorporated a much larger antenna affixed to a standard size pair-trawl (trawl with same dimensions as above except where adapted to fit the larger-size fish passage opening). This antenna consisted of two, three-coil components, (outside dimension of each component was $2.6 \times 3.0 \mathrm{~m}$ ) affixed together and separated by a 1.5-m-long webbed fish-passage tunnel. Inside dimensions of individual coils measured 0.75 by $2.8 \mathrm{~m}$.

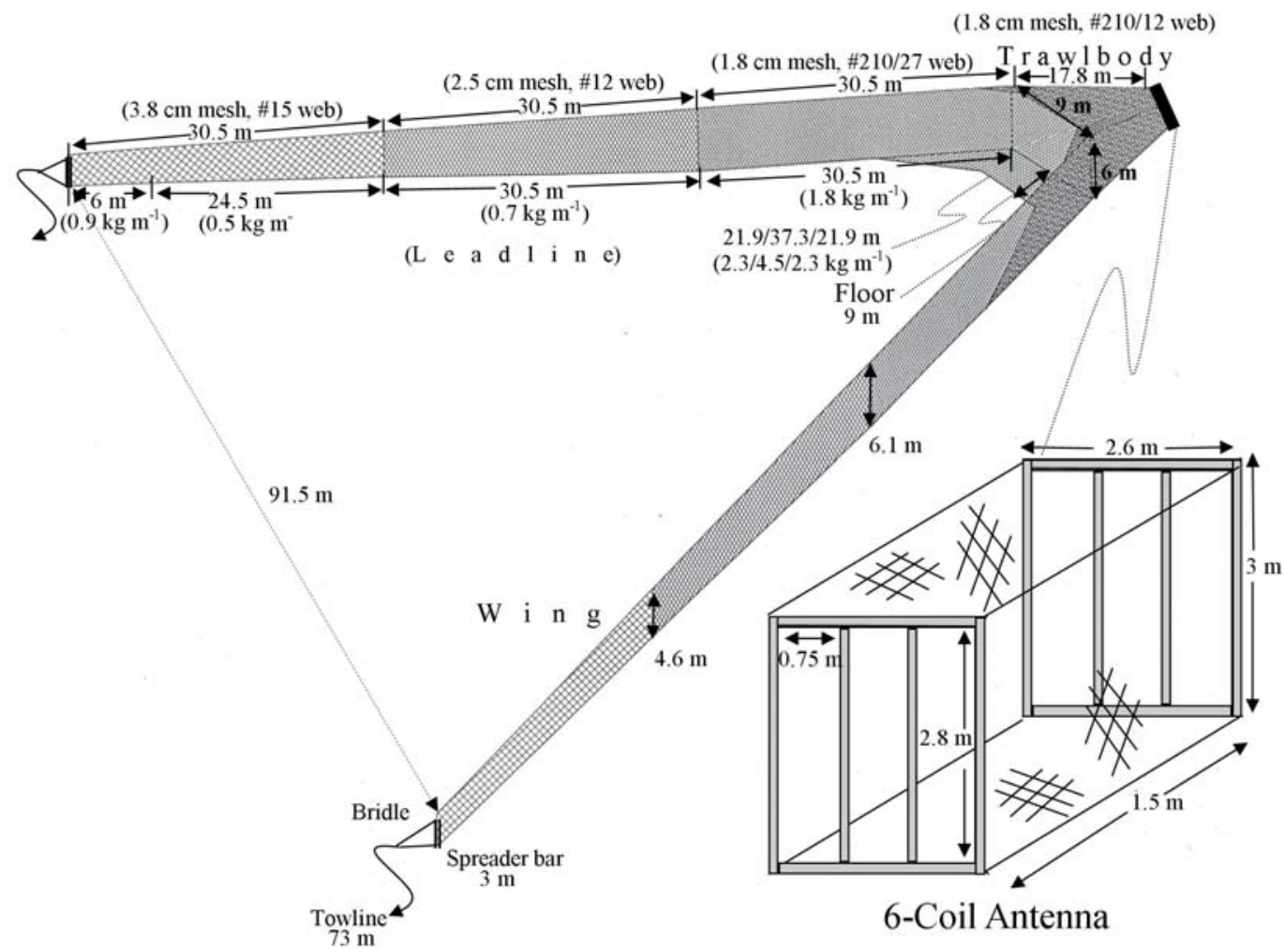

Figure 3. Design of the surface pair trawl and "matrix" antenna used to sample PIT-tagged juvenile salmonids in the Columbia River estuary (rkm 75), 2008. 
Each component of the matrix antenna weighed approximately $114 \mathrm{~kg}$ in air and required an additional $114 \mathrm{~kg}$ of lead weight to sink in the water column (452 kg total weight in air). A PIT-tag transceiver was mounted in a water-tight box on a small pontoon raft tethered at the rear of the trawl. Cables from the underwater antenna led to the box, which contained a wireless modem to transmit PIT-tag detections and electronic status reports from the transceiver to a computer stationed aboard a tow vessel.

\section{Electronic Equipment and Operation}

The two-coil, cylindrical antenna system used essentially the same electronic components and procedures as in earlier years with periodic upgrades when indicated. In 2008, we used Digital Angel ${ }^{\dagger}$ model FS1001M transceivers and Minimon software available from PTAGIS. The 10-m-long pontoon barge was towed attached to the trawl near the antenna, and a gasoline generator powered all electronic equipment. Associated PIT-tag detection electronics were mounted in the cabin of the barge, and cables led underwater to tuner ports, one on each of two detection coils. A video camera mounted inside the antenna tunnel was used to monitor fish passage on a VCR/TV housed in the barge.

Once the antennas were operational, the Minimon software automatically recorded date, time, tag code, coil identification number, and GPS location. For each sampling cruise, written logs were maintained noting the time and duration of net deployment, total detections, number of impinged fish, and start and end of each net-flushing period.

Electronic components for the matrix system were contained in a $0.8-\mathrm{m}$-long by 0.5-m-wide by 0.3 -m-deep water-tight box mounted on a 2.4 -m-long by 1.5 -m-wide pontoon raft. A DC power source was used for both the Digital Angel model FS-1001M PIT-tag transceivers and the underwater antenna. Data were then wirelessly transmitted to a computer onboard one of the tow vessels, and GPS position of the tow vessel was recorded along with date, time, tag code, and coil identification number in the Minimon data file.

PIT-tag detection data files were periodically (about weekly) uploaded to PTAGIS using standard methods described in the PIT-tag Specification Document (Stein et al. 2004). The specification document, PTAGIS operating software, and user manuals

$\varlimsup^{\dagger}$ Use of trade names does not imply endorsement by the National Marine Fisheries Service, NOAA. 
are available via the Internet (PSMFC 2008). Pair-trawl detections in the PTAGIS database were identified with site code “TWX” (towed array experimental).

Records of PIT-tagged fish detected at Bonneville Dam were downloaded from PTAGIS for comparison with our detections (PSMFC 2008). Also, the sites, dates, and times of barge loading, along with corresponding release dates, times, and locations (rkm) of transport barges were provided by the USACE. An independent database (Microsoft Access) of detection information was also maintained to facilitate data management and analysis. The date and river kilometer of barge release were assigned to an independent subset of transported fish based on the last detection date recorded at the transport dam.

\section{Detection Efficiency Tests}

We used similar procedures as in earlier years for evaluating electronic performance of the various trawls and antenna systems, none of which required the release of test fish (Ledgerwood et al. 2005). For these tests, a 2.5-cm-diameter PVC pipe with a small plastic funnel on each end was positioned through the center of each antenna. The pipe extended past each end of the antenna beyond the range of the electronic field (at least $0.5 \mathrm{~m}$ ). We evaluated detection efficiency by attempting to detect test PIT-tags attached at known intervals and orientations to a vinyl-coated tape measure passed through the pipe. Due to the basin-wide increase in fish implanted with SST PIT-tags, we created two vinyl tapes with identical tag-spacing intervals and orientations to determine detection efficiency of both tag types (Appendix Tables 1-2): one tape was fitted with ST PIT-tags and the second with SST PIT-tags.

Detection efficiency, the ability to read PIT-tags, was evaluated for each system at the center of the antenna (Figures 4 and 5) and was expected to be positively correlated with orientation, spacing, and proximity to the electronic field. With each new antenna design, we attempted to concurrently maximize the fish-passage opening and potential for detections. These tests were conducted in the weakest area of the antenna field, with tags dispersed and oriented in fixed positions along the vinyl tape-measure. Test results did not reflect actual reading efficiency for PIT-tagged fish because they generally pass in the more optimal areas of the antennas with their tags perpendicular to the electronic field.

We chose densities and orientations along the tape such that not all tags would be detected; the relative consistency of tag detection helped validate electronic tune and identify possible problems with the electronics. During tests, we suspended the antennas underwater and pulled the tape back and forth several times through the PVC pipe. The start time of each pass was recorded in a logbook, and we used standard PIT-tag software 
to record detections. Efficiency was calculated as the total number of unique target tags decoded during each pass divided by the total target tags passed through the antenna. The cylindrical system was tested about once weekly, while the matrix system was evaluated at the beginning and end of the sample period.

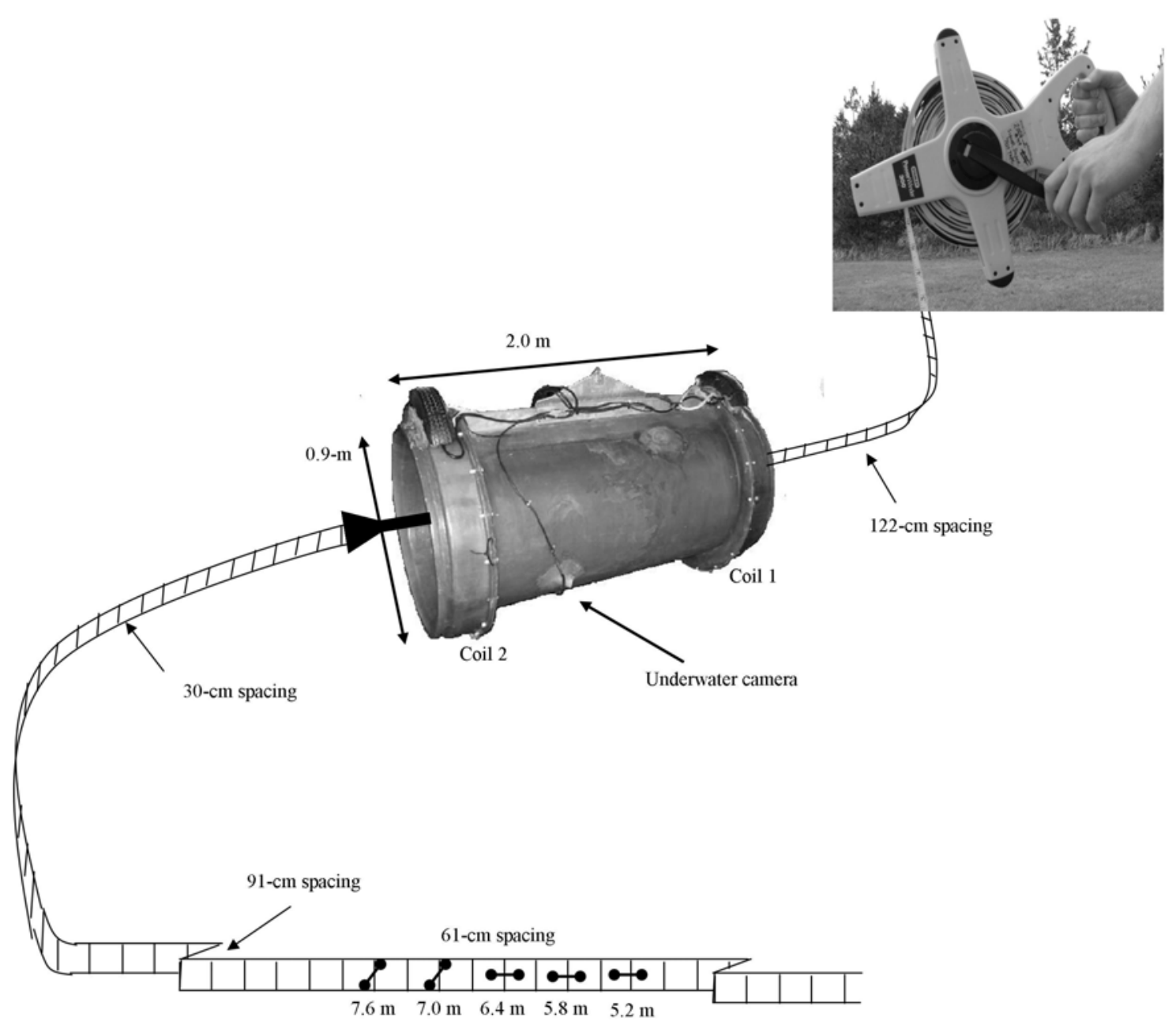

Figure 4. Funnel testing system depicting a vinyl tape measure fitted with test tags and being passed through the center of the two-coil cylindrical antenna system, 2008. Tags attached to the tape were oriented at 0 and 45 degrees and spaced in combinations at 30, 61, 91 and $122 \mathrm{~cm}$ apart. 


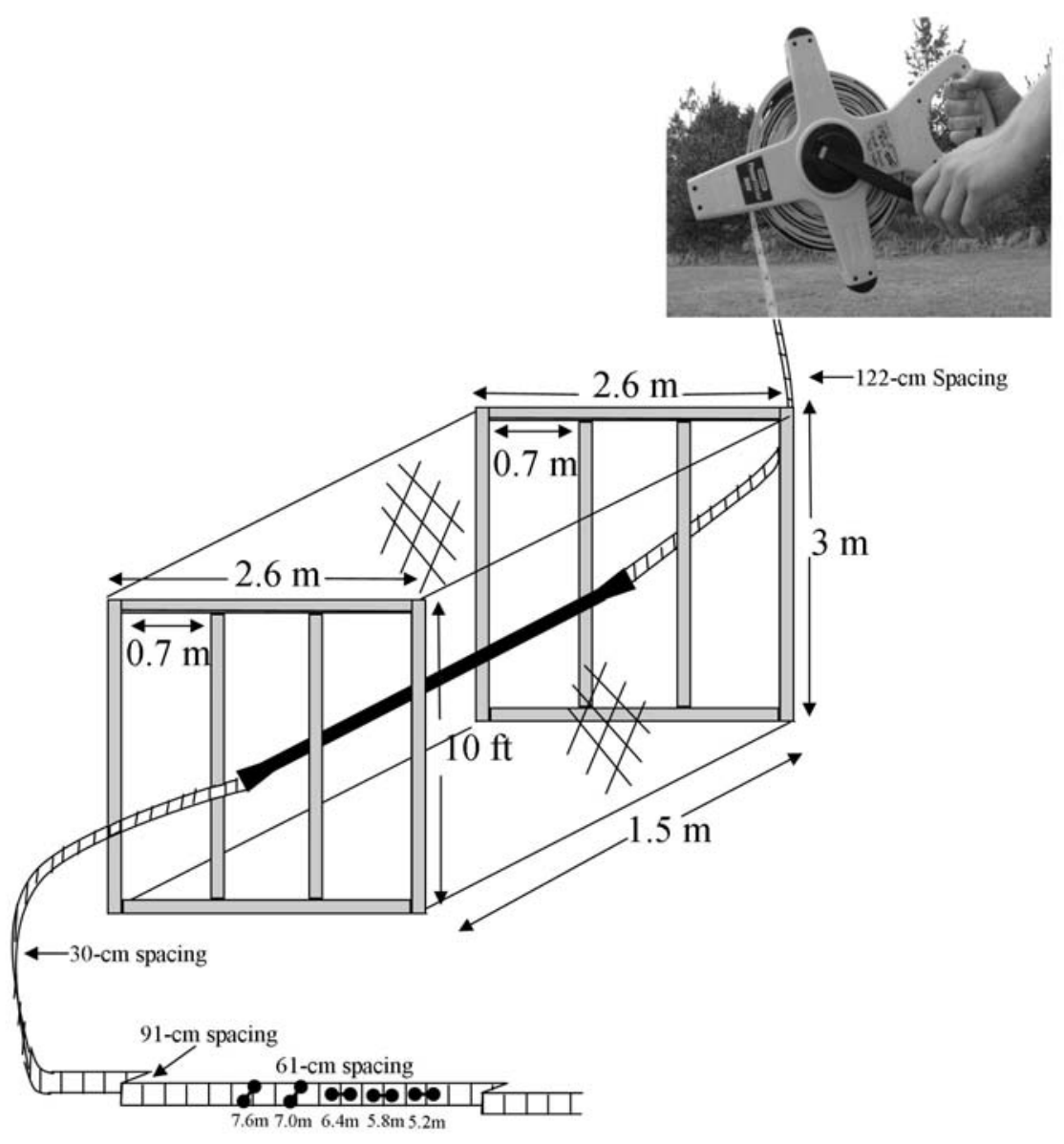

Figure 5. Funnel testing system depicting a vinyl tape measure fitted with test tags being passed through the center of the front and rear component of the six-coil matrix antenna system, 2008. Tags attached to the tape were oriented at 0 and 45 degrees and spaced in combinations at 30, 61, 91 and $122 \mathrm{~cm}$ apart. 


\section{Impacts on Fish}

An underwater camera was used during the day on both sample systems to monitor debris accumulation near the antenna and cod-end of the net. Other sections of the net were monitored visually from the skiff and tow vessels, and accumulated debris was removed as necessary. The net-flushing procedures were also effective at breaking debris loads free from the net, which enabled debris to pass out of the trawl through the antenna opening. We also adjusted sample operations upon indication of possible impacts to fish in the trawls. For example, when debris accumulated, we reduced tow speed and utilized zippers located just forward of the antenna to remove material from the cod-end. When debris accumulation was extremely heavy in the cylindrical antenna system, we disconnected the electronics and inverted the entire net for cleaning, then reattached the antenna to continue sampling. The net was also inverted prior to each retrieval of the cylindrical system.

The matrix trawl system differed from the older cylindrical system in that it enabled retrieval directly onto a tow vessel without detachment of the antenna or inversion the trawl. One drawback of this design was the occasional accumulation of significant quantities of debris, which had been emptied from the net during the inversion process with the cylindrical system. The larger fish-passage opening of the matrix antenna was more efficient at passing debris, but occasionally accumulations of debris had to be removed by hand. This could be done through zippers in the trawl body either during the retrieval process, which required longer drifts, or back at the dock. During debris-removal activities and net-retrieval and redeployment procedures for either trawl system, we recorded impinged or trapped fish as mortalities in operations log books.

\section{Statistical Analyses}

Detection data from the estuary are essential to estimate survival of juvenile salmonids at Bonneville Dam, the last dam encountered by seaward migrants (Muir et al. 2001; Williams et al. 2001; Zabel et al. 2002). The probability of survival through an individual river reach is estimated from PIT-tag detection data using a multiple-recapture model for single release groups (CJS model) (Cormack 1964; Jolly 1965; Seber 1965; Skalski et al. 1998). This model requires detection probability estimates at the lowest downstream detection site (i.e., Bonneville Dam), and these estimates are calculated using detections downstream from the dam obtained with our trawl. Complete methodologies and analyses of these data for all river reaches were presented in the companion study by Faulkner et al. (2009). 


\section{RESULTS AND DISCUSSION}

\section{Trawl Detections}

In 2008, we detected 16,563 PIT-tagged juvenile salmonids using the cylindrical and matrix detection systems at Jones Beach. Fish detected were of various species, runs, and rearing types (Table 1). For example, $61 \%$ of our detections were Chinook salmon, $36 \%$ were steelhead, and the remaining $3 \%$ were other salmonid species. Of these same detections, $16 \%$ were wild, $81 \%$ were hatchery, and $3 \%$ had no release information available in PTAGIS. River basin source and migration history for PIT-tagged fish detected in the estuary are shown in Figure 6. Annual differences in PIT-tagging strategies, hydrosystem operations, and proportions of fish transported each year contributed to variations in the proportions from each source. These differences generally complicate multiyear comparisons of trawl detections among sources, species, and run or rearing types; however, proportions in 2008 were similar to those in 2007. We present a series of results comparing these years.

Table 1. Species composition and rearing-type history for PIT-tagged fish detected in the cylindrical antenna and matrix trawl systems near river kilometer 75, 2008.

\begin{tabular}{lrrrr}
\hline & \multicolumn{3}{c}{ Rear type } & \\
\cline { 2 - 4 } Species/run & Hatchery & Wild & Unknown & Total \\
\hline Spring/summer Chinook salmon & 6,171 & 1,051 & 175 & 7,397 \\
Fall Chinook salmon & 2,657 & 39 & 39 & 2,735 \\
Coho salmon & 287 & 4 & 0 & 291 \\
Steelhead & 4,205 & 1,580 & 165 & 5,950 \\
Sockeye & 87 & 35 & 0 & 122 \\
Sea run Cutthroat & 0 & 0 & 0 & 0 \\
Unknown & 0 & 0 & 68 & 68 \\
Grand total & 13,407 & 2,709 & 447 & 16,563 \\
\hline
\end{tabular}


PIT-tagged juvenile salmonids

detected in the estuary, 2008

$$
\mathrm{n}=16,563
$$

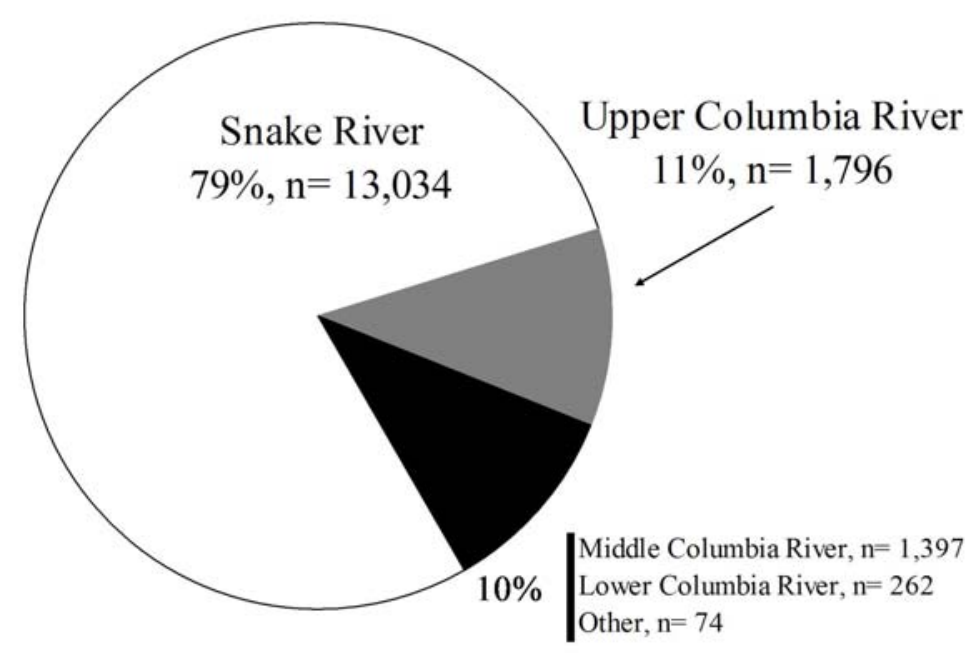

Detected at Bonneville Dam $13 \%$

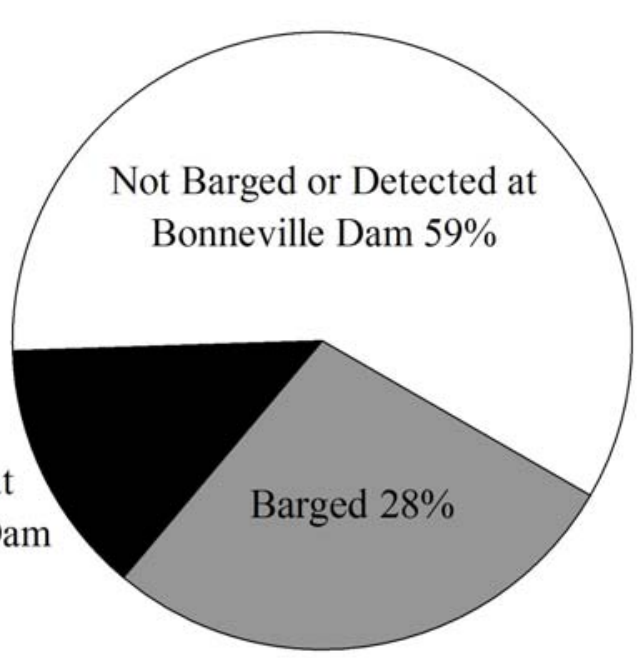

Figure 6. River basin sources and migration histories of PIT-tagged fish detected in the estuary (rkm 75), 2008. 
During 2008, the cylindrical antenna system was operated for $212 \mathrm{~h}$ and the matrix system for $767 \mathrm{~h}$, resulting in 979 sample hours and 16,563 fish detections. In 2007, we sampled with the cylindrical system exclusively for 1,059 h and detected 19,186 fish (Figure 7). According to the PTAGIS database, there were more PIT-tagged fish released in 2008 than in any previous year; however, we detected approximately 2,600 fewer fish than in 2007.

Aside from the type of trawl detection system used, there are many variables associated with annual detection numbers in the estuary. For example, mean flow volumes were considerably higher in the Columbia River from mid-April through the end of June in 2008 than in $2007\left(8,714 \mathrm{~m}^{3} \mathrm{~s}^{-1}\right.$ vs. 6,858 $\mathrm{m}^{3} \mathrm{~s}^{-1}$, respectively; Figure 8). Higher flows speed migration through the sample area and thus tend to reduce detection numbers. Higher flow volumes and debris loads, sometimes extreme in 2008, resulted in less sample time during the height of the spring migration than in previous years. We speculate that this loss of sample time during peak migration contributed to a lower sample efficiency and fewer overall detections than in 2007.

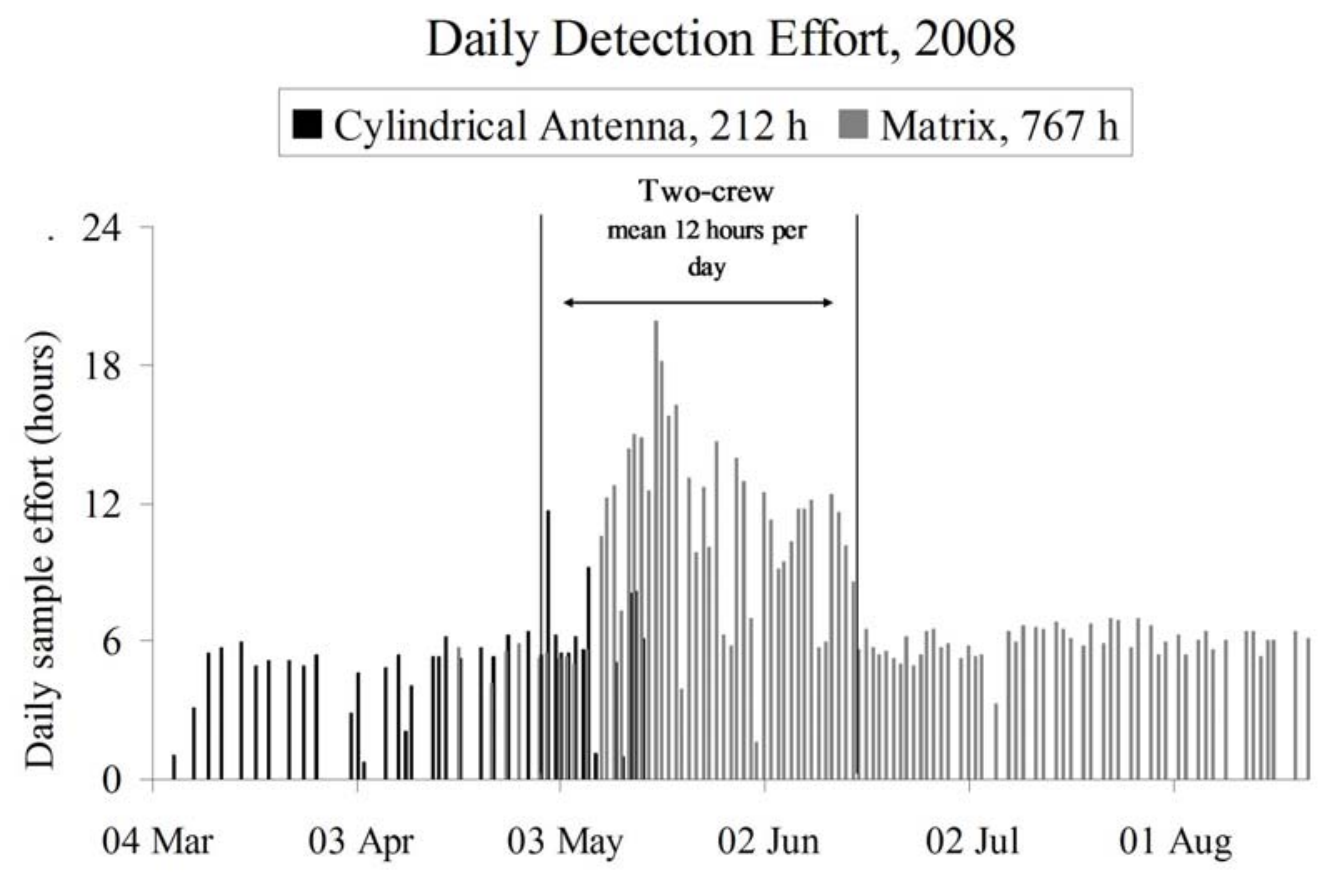

Figure 7. Daily sampling hours using the cylindrical and matrix PIT-tag detection system in the upper Columbia River estuary (rkm 75), 2008. 
Columbia River flow volume at Bonneville Dam, 1998 - 2008

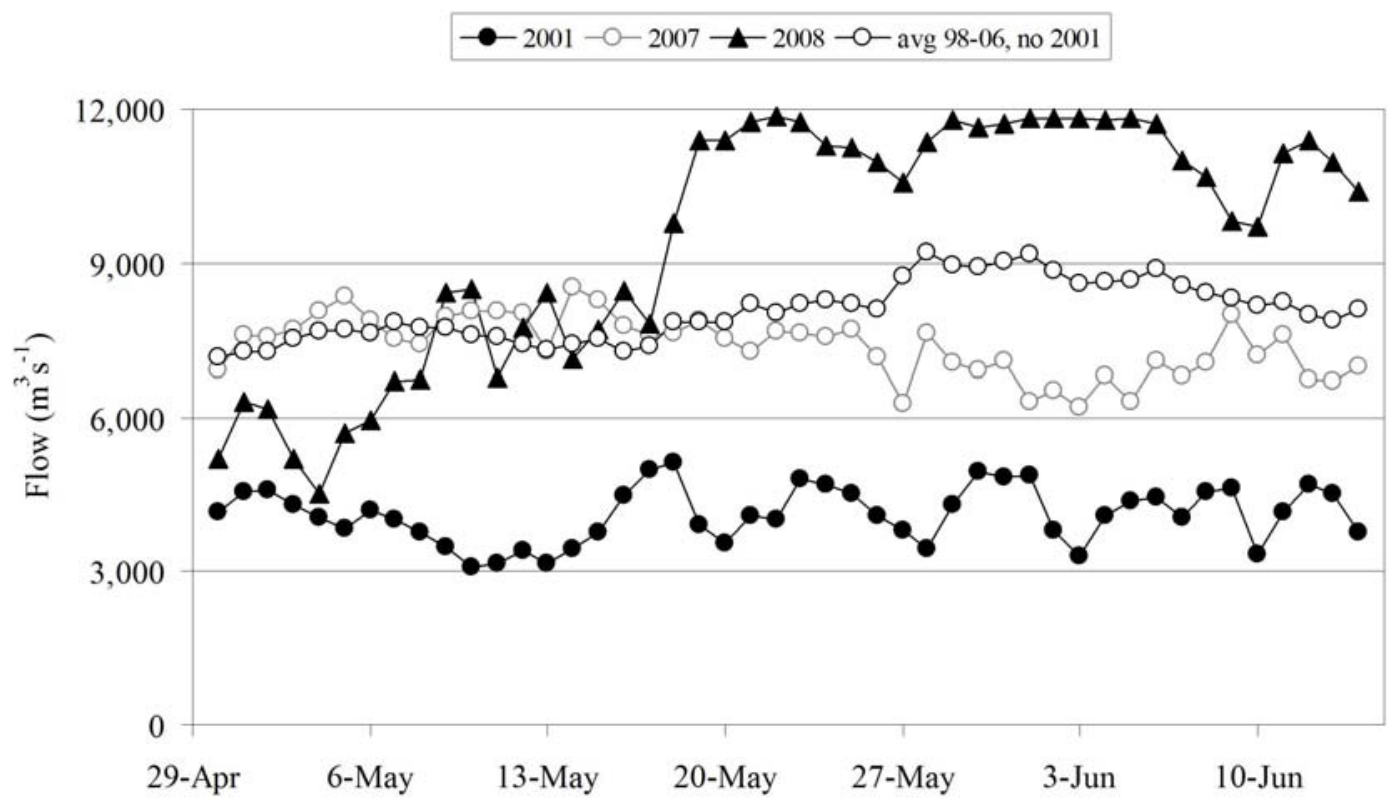

Figure 8. Columbia River flows at Bonneville Dam during the two-crew periods 2007 through 2008, as compared to the average flow from 1998 to 2006.

Drought-year flows for 2001 are also shown for comparison. 


\section{Matrix System}

Initial testing of a newly designed "matrix" antenna system occurred in 2006 and 2007, but only through simultaneous deployments of both the cylindrical and matrix systems could we truly assess performance of the matrix system. Test deployments in 2006 utilized a smaller trawl and single component (two-coil) matrix antenna. In 2007 we modified a full-sized trawl and installed a picking davit on the stern of one of our 41-ft tow vessels to enable us to safely deploy the matrix antenna with a standard-sized trawl. Those tests proved satisfactory; thus during winter 2007, we modified a second tow vessel with a matrix-capable davit (for backup) to prepare for testing the old and new systems simultaneously during a time period of relatively high PIT-tag fish densities in May 2008. We also constructed a new trawl with a trawl body/cod-end matching the dimensions of the matrix antenna. A second trawl body was constructed enabling a retrofit to the forward section of older trawls for backup. If simultaneous sampling results revealed a higher detection rate on the matrix system, then a full transition to the matrix system was planned.

For simultaneous testing, we required four tow vessels, but we had only three 41-footers. Therefore, we substituted two 26-ft gas-powered vessels, arranged in tandem, on one-wing of the matrix trawl and used a normal 41-ft tow vessel on the other wing. The 41-ft tow vessels were kept at normal tow power (1100 RPM) when used with the cylindrical antenna system by matching speed of the 41-footers with that of the gas-powered tow vessels. As a result, both systems moved through the water at almost identical speed and were fished within $1 \mathrm{~km}$ of each other through most of the deployments.

On 13, 14, and 15 May, both the cylindrical and matrix systems were deployed during day-shift (Figure 9). Generally, the cylindrical antenna crew would depart and deploy their system about $1 \mathrm{~h}$ prior to departure/deployment of the matrix system. The matrix system was deployed slightly upstream from the cylindrical system on day 1 and downstream from it on days 2 and 3. The goal was to sample as close to each other as prudence allowed. Flush times were synchronized between the two systems, and detection numbers recorded on both systems in our standard practice. A total of 1,055 PIT-tagged fish were detected during simultaneous sample periods (Appendix Table 3). A total of 76 fish were detected by both systems (median travel times between systems was 23.6 min; Appendix Table 3). 
In total the cylindrical antenna system detected 339 fish during $14.5 \mathrm{~h}$ of simultaneous sampling and the matrix system, 716 (53\% more). Moreover, the higher rates of detection with the matrix system were consistent, as only 3 of 34 total simultaneous net flushes of the cylindrical antenna system had more fish detected than flushes with matrix system. Deployment/retrieval procedures were also simplified and safer using the matrix system; thus, following the day-shift deployment of 15 May, the cylindrical antenna and related equipment were retired, and we continued sampling exclusively with the matrix system.

Tandem Sampling Detections for the Cylindrical Antenna and

Matrix Trawl Systems, 2008

- Matrix System $\square$ Cylindrical Antenna System

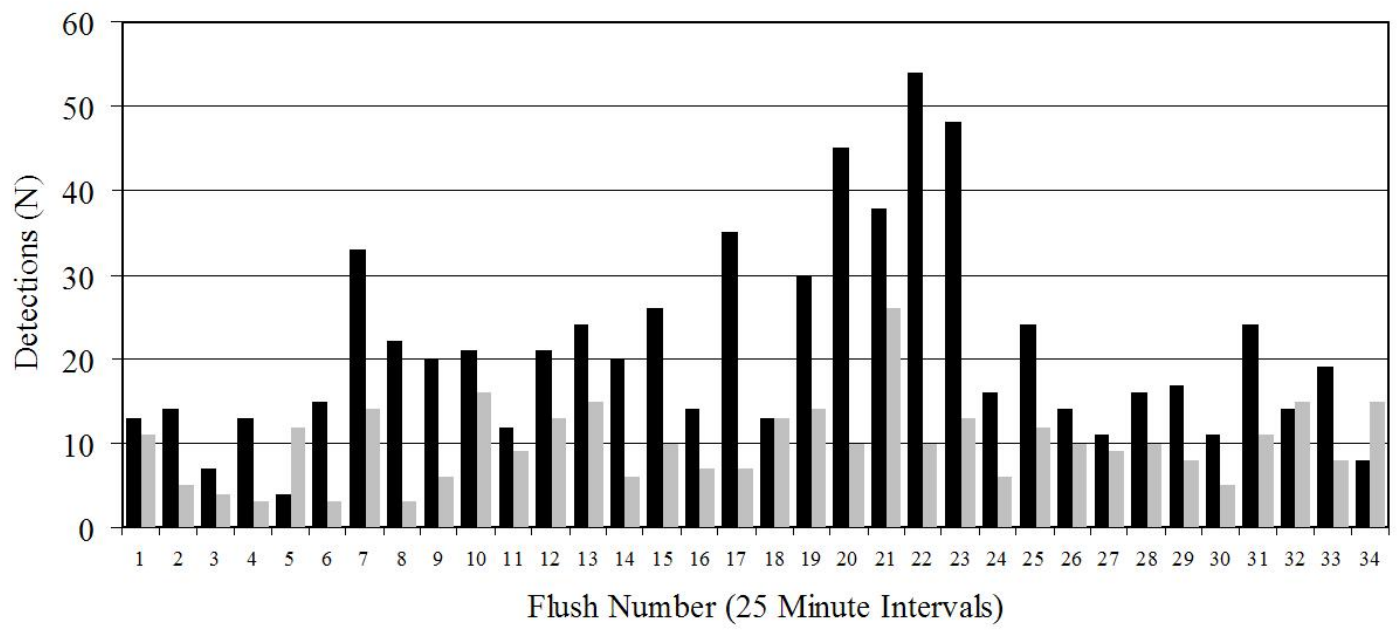

Figure 9. Results of tandem sampling conducted using the matrix and cylindrical antenna systems at rkm 75 on 13, 14, and 15 May 2009. Results show a 53\% increase in overall detections with the matrix system after $14.5 \mathrm{~h}$ of sampling. Net flushes (occurring every $20 \mathrm{~min}$ and lasting for $5 \mathrm{~min}$ ) were conducted simultaneously and required both wings of the trawl to be drawn together to a position parallel to the outside of the trawl body. 


\section{Detection Efficiency}

Test tags that were oriented perpendicular to the electronic field were detected at equal or higher rates than those placed at an angle. Differences in detection efficiency were observed primarily when the test tape was passed through the center of the antennas rather than when the tape was passed near the edges (the optimal area within the electronic field and where most fish pass). Therefore, these in situ evaluations of detection efficiency were a rigorous test of antenna performance. Decreased detection efficiency associated with collision of multiple PIT-tag codes within the electronic field was commonly associated with shorter spacing of tags and their orientation within the coil. Two types of PIT tags were commonly implanted in fish in 2008, older-style ST tags and newer-style SST tags having longer read ranges. We tested individual coils of our antennas with both types of tags.

Individual coils of the 3-coil matrix components were $0.7 \mathrm{~m}$ wide by $2.8 \mathrm{~m}$ tall (inside dimensions). Were unable to read either ST or SST test tags when the test tape was passed through the center of the antenna and tags were spaced $30 \mathrm{~cm}$ apart and oriented perpendicular to the electronic field (Figure 10). When spacing between tags was increased to $61 \mathrm{~cm}$, detection efficiency for respective ST and SST tags was 88 and $90 \%$ for tags that were perpendicular and 83 and $68 \%$ for tags at a 45 -degree angle to the field. For test tags passed perpendicular to the field, reading efficiency increased to $100 \%$ for both test tag types, and for tags passed at 45 degrees, reading efficiency increased to $90 \%$ for ST and $100 \%$ for SST tags. 
6 Coil Matrix System, 2008

Detection Rate of Test ST Pit-Tags

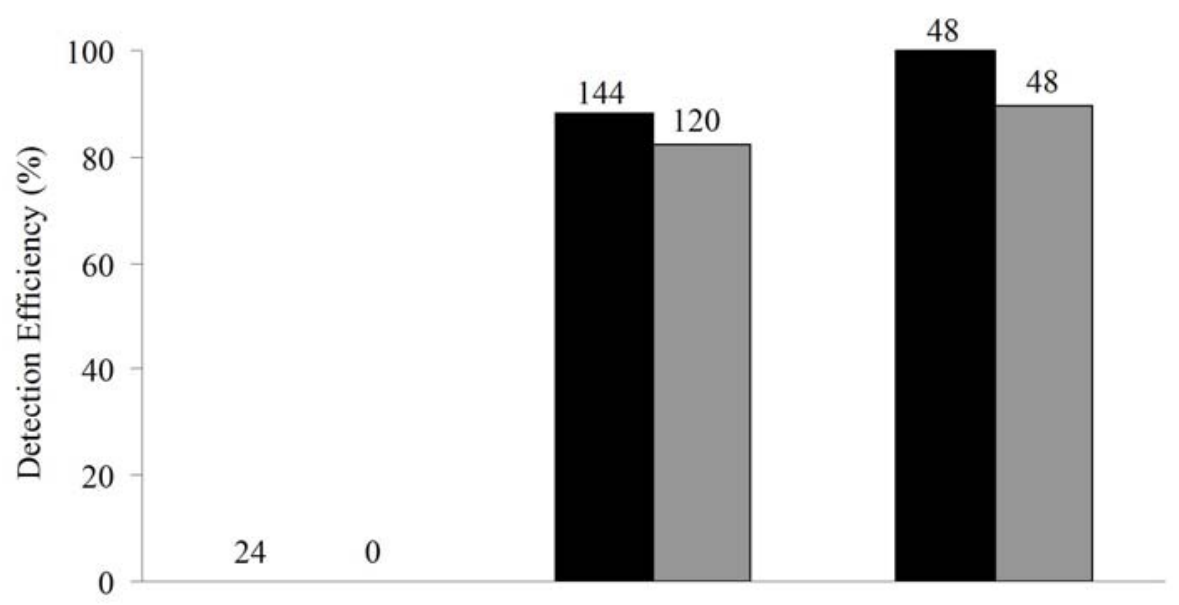

ロ $0 \square 45$

Detection Rate of Test SST Pit-Tags

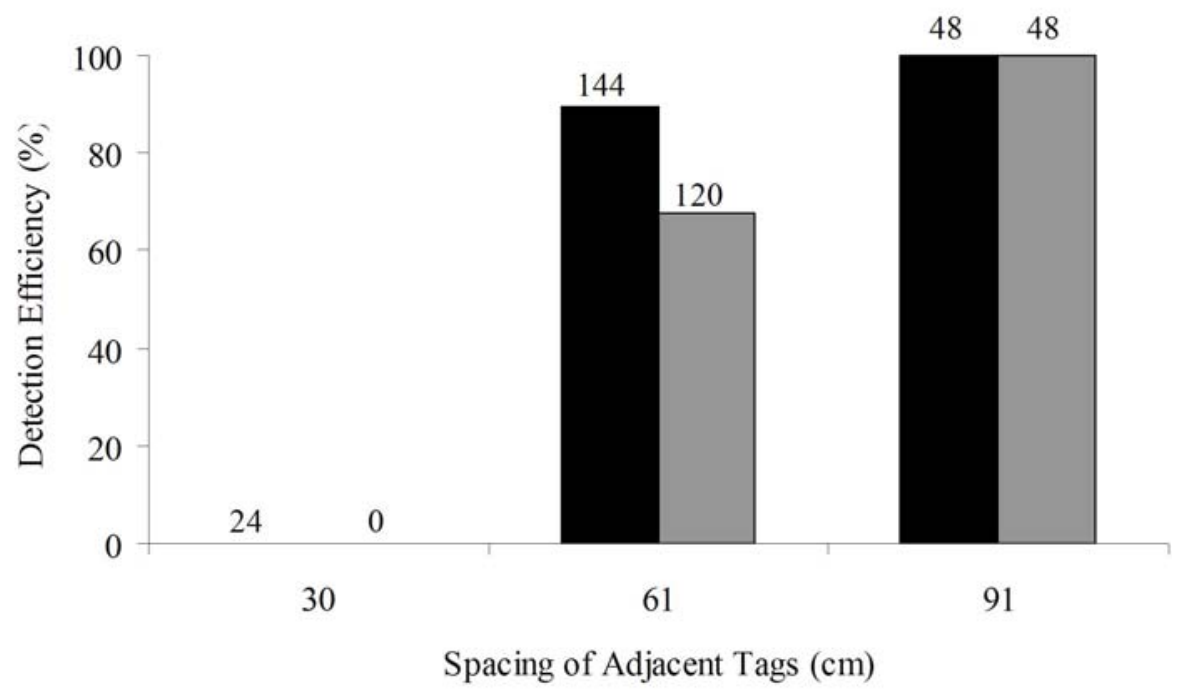

Figure 10. Average detection efficiency determined by using ST and SST-style PIT-tags attached to vinyl tape measures in 2008. Various spacing between tags and orientation to the electronic field were used, and all tape configurations were identical. Tags were repeatedly passed through the center of each $0.7 \mathrm{~m}$ by $2.8 \mathrm{~m}$ matrix antenna (total potential tags listed above the bars). 
Detection efficiencies of individual coils for the 0.9-m-diameter antenna of the cylindrical system were evaluated in situ periodically (about weekly) until replaced by the 6-coil matrix antenna system after 15 May. Overall, the 0.9-m-diameter antenna read 92 and $85 \%$ of ST and SST tags, respectively (Table 5). Detection efficiency of the original two-coil matrix antenna (1.1 m by $2.8 \mathrm{~m} \mathrm{ID)}$ was lower than that of the newer three-coil matrix antenna, averaging 74 and 66\% respectively, for ST and SST test tags.

Table 5. Average detection efficiencies of three PIT-tag antenna designs for two tag types compared by passing test tags at various spacing and orientations on a vinyl tape through the center or near the side of each antenna, 2008.

\begin{tabular}{lccccc}
\hline & & & \multicolumn{3}{c}{ Antenna efficiency (\%) } \\
\cline { 3 - 6 } Antenna (dimensions) & Tag type & $\begin{array}{c}\text { Total target } \\
\text { tags (N) }\end{array}$ & $\begin{array}{c}\text { Overall } \\
\text { (center) }\end{array}$ & $\begin{array}{c}\text { Maximum } \\
\text { (center) }\end{array}$ & $\begin{array}{c}\text { Maximum } \\
\text { (side) }\end{array}$ \\
\hline Cylindrical (0.9-m diameter) & ST & 1,024 & 92 & 94 & 97 \\
Cylindrical (0.9-m diameter) & SST & 128 & 85 & 91 & 91 \\
Matrix (1.1- $\times 2.8$-m perimeter) & ST & 128 & 74 & 88 & \\
Matrix (1.1- $\times 2.8$-m perimeter) & SST & 128 & 66 & 75 & \\
Matrix (0.7- $\times 2.8$-m perimeter) & ST & 384 & 83 & 94 & \\
Matrix (0.7- $\times 2.8-m$ perimeter) & SST & 384 & 80 & 94 & \\
\hline
\end{tabular}

We also evaluated detection efficiency of the matrix antenna system by comparing daily proportions of fish detected on each coil (Figure 11). Ninety-five percent of all fish detected were first recorded on one of the three front coils, and the remaining $5 \%$ were detected only on one of the three rear coils (missed by the front component). Some fish were detected only on the front coils, either because they were missed by the rear coils or possibly because they escaped the trawl by swimming forward and out of the mouth. Eight-three percent of all fish were detected on the rear coils.

The two-component, front-to-rear antenna design provided redundant reads for fish exiting the trawl. This was particularly valuable during periods when high numbers of PIT-tagged fish were passing. When numbers of unique records of PIT-tagged fish recorded on the front and rear coils were radically different, we suspected problems with the electronics. Orientation of fish to the electronic field was thought to be better for coils at the rear of the fish-passage opening, since past results indicated that fish orientation may improve during passage through the opening. 


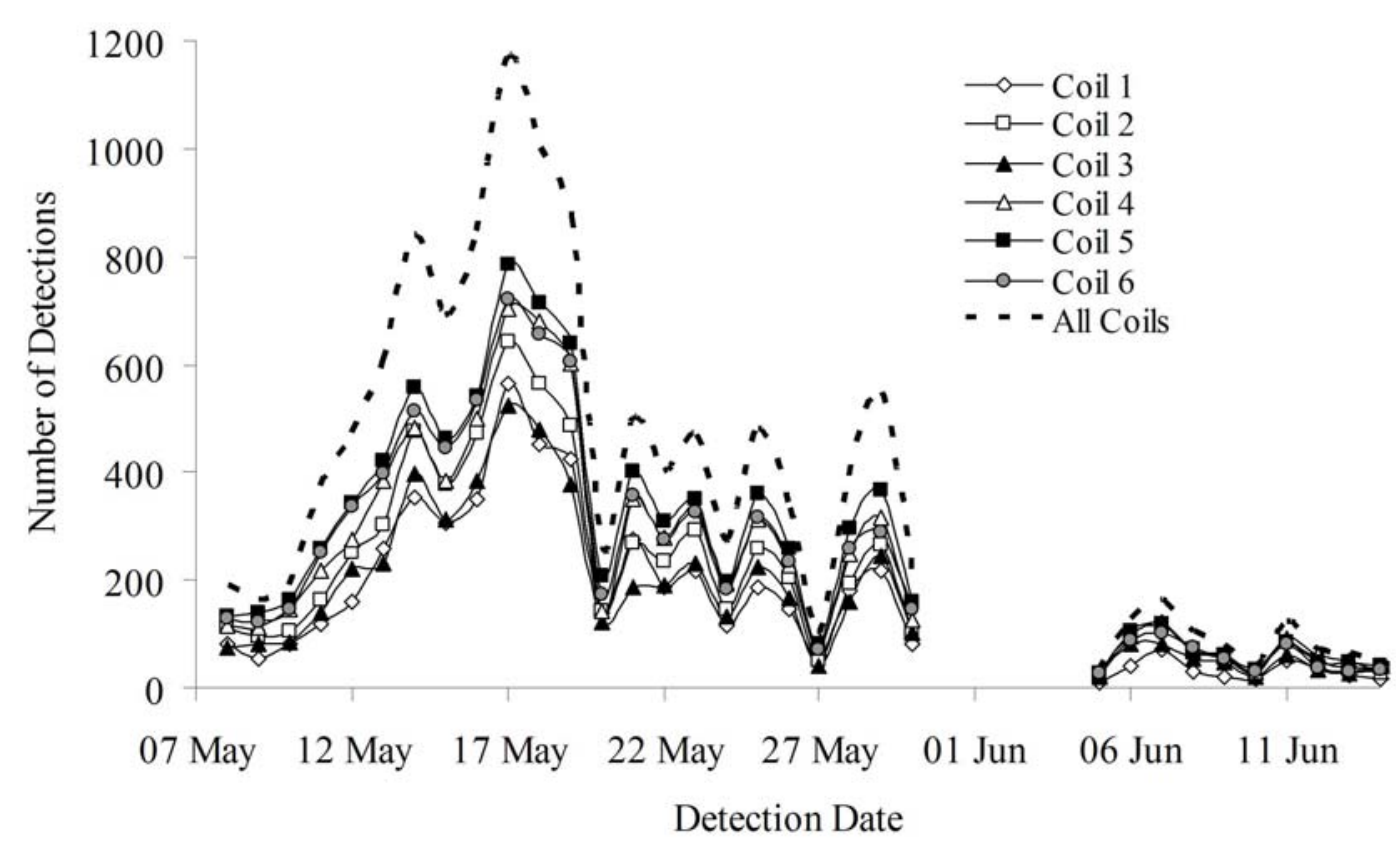

Figure 11. Daily detection rates by individual antenna coils used in the matrix trawl system during the two-crew sample period (30 April to 14 June). Coils 1-3 form the rear component and coils 4-6 form the front component. Inside dimension of the coils was $0.7 \mathrm{~m}$ wide by $2.8 \mathrm{~m}$ tall, and coils were connected by net around the perimeter, maintain a $1.5-\mathrm{m}$ gap between the front and rear.

\section{Impacts on Fish}

During inspection or retrieval of the trawls, we recovered juvenile salmonids that had been inadvertently injured or killed during sampling. In 2008, we recovered 22 of these fish while using the cylindrical antenna system and 168 while using the matrix system (Appendix Table 4). Due to the net inversion process required with the cylindrical antenna system, it is possible that additional fish were unknowingly injured or killed. However, in previous years, divers have inspected the trawl body and wing areas of the nets underway and have reported that fish rarely swam close to the webbing. Rather, fish tended to linger near the entrance to the trawl body and directly in front of the antenna, areas where visual orientation to the sample gear is enhanced. 
Through the years we have eliminated many visible transition areas between the trawl, wings, and other components. These visible transitions mainly were found in the seams joining sections with different web sizes or weights. We also now use a uniform color (black) of netting for the trawl body and cod-end areas, which reduced fish training and expedited passage out of the net. We continued to flush the net (bring the trawl wings together) every 15 min to expedite fish passage through the antenna. The purpose of flushing is to reduce delay, and possible fatigue, of fish that may be pacing the net transition areas or lingering near the antenna components. While volitional passage through the antenna occurred during tows with the wings extended, we continued to bring the wings together to flush fish (and debris). A majority of fish detections were recorded during these 5-min net-flushing periods.

\section{Sampled PIT-Tagged Fish}

There were 49,248 yearling Chinook salmon and 87,628 steelhead PIT tagged for the NMFS transportation study and released upstream from our sample site. In addition, a total of 30,344 yearling Chinook salmon and 40,967 steelhead were diverted at Snake and Columbia River dams for transport. Including the diverted river-run fish and fish tagged for other studies, totals of 64,846 yearling Chinook salmon and 47,894 steelhead were transported and released upstream from our sample site. Of those released, we detected 1,886 yearling Chinook salmon and 1,183 steelhead in the upper estuary near river kilometer 75 . Analyses of these detections will be reported independently (Magie et al. in press)

Of inriver migrating fish from the Snake and Columbia River basin, 63,204 yearling Chinook salmon and 28,115 steelhead were detected passing Bonneville Dam. Of these detected fish, we subsequently detected 1,049 yearling Chinook salmon and 967 steelhead (Appendix Table 5). These repeat detections in the estuary of fish previously detected at Bonneville Dam are essential, and are often the limiting component in estimates of survival probabilities for these species to the tailrace of Bonneville Dam.

Beginning in 2004, fish could exit the second powerhouse forebay at Bonneville Dam through a corner-collector flume, which carried fish to the tailrace. Of all routes of passage to the tailrace of Bonneville Dam, including spillway or turbines, only fish guided into the juvenile bypass system were interrogated for PIT-tags. Detection numbers at Bonneville Dam were much reduced during 2004 and 2005 as a result of the successful operation of the corner collector, which lacked detection capability. Beginning in 2006, a PIT-tag detection system was installed in the corner collector. Since that year, about half of all PIT-tagged fish detected at Bonneville Dam have been 
recorded passing via the corner-collector system, and the remaining fish have been detected in the juvenile bypass facility. The addition of PIT-tag detection capability in the corner collector at Bonneville Dam has improved the precision of survival estimates to the tailrace of Bonneville Dam.

As in previous years, only a small portion of either transported or inriver migrant fish passed through the estuary before or after the trawl sampling period. In 2008 we estimated that $81 \%$ of the transported fish and $60 \%$ of fish detected at Bonneville Dam were at or near river kilometer 75 during our daily two-crew trawling period from 30 April to 14 June (Table 6). During the two-crew sample period, we detected $1.7 \%$ of the barged PIT-tagged juvenile Chinook salmon released and $2.4 \%$ of those previously detected at Bonneville Dam; for steelhead, we detected 1.9\% of the barged fish and 3.6\% of fish previously detected at Bonneville Dam.

Table 6. Detections of PIT-tagged fish released from barges and inriver migrant fish detected previously at Bonneville Dam during the intensive two-crew daily sample period in the estuary from 30 April to 14 June 2008. The "release" totals for PIT-tagged fish during this sample period were selected allowing two days for fish to travel from Bonneville Dam to the sample area.

\begin{tabular}{lcccccc}
\hline & \multicolumn{3}{c}{ Barged } & \multicolumn{3}{c}{ In-river } \\
\cline { 2 - 7 } & Released & Detected & $\%$ & Released & Detected & $\%$ \\
\hline Chinook salmon & 138,826 & 2,363 & 1.7 & 31,276 & 760 & 2.4 \\
Steelhead & 84,109 & 1,602 & 1.9 & 23,345 & 831 & 3.6 \\
\hline
\end{tabular}




\section{Survival Estimates of Inriver Migrants to the Tailrace of Bonneville Dam}

Detection data from the trawl are essential for calculating survival probabilities for juvenile salmonids to the tailrace of Bonneville Dam, the last dam encountered by seaward migrants (Muir et al. 2001; Williams et al. 2001; Zabel et al. 2002). Detections of yearling Chinook salmon and steelhead arriving at McNary Dam were pooled weekly, and survival probabilities of fish released in the Snake and mid-Columbia Rivers were estimated from McNary to John Day, John Day to Bonneville, and McNary to Bonneville Dams. An example of weekly pooled survival estimates is shown in Table 7.

Weighted annual survival estimates were compared for the years 1999-2008 for both Snake and mid-Columbia River basin stocks (Figure 12). In some years, an insufficient number of PIT tags were released for survival estimates for species from one watershed or the other. However, there does not appear to be a general trend in survival between the two watershed sources for either species. Annual survival estimates from the tailrace of McNary Dam to the tailrace of Bonneville Dam for Snake River stocks of yearling Chinook salmon ranged from 53.7\% in 2008 to 84.2\% in 2006. Similar estimates for mid-Columbia River stocks ranged from 59.3\% in 2008 to $76.7 \%$ in 2003. Survival estimates for Snake River stocks of steelhead ranged from 25.0\% in 2001 to $77.0 \%$ in 1998 (63.9\% in 2008). Similar estimates for mid-Columbia River stocks ranged from 39.2\% in 2007 to $74.2 \%$ in 1999 (estimate not available for 2008). Complete analyses of these data are reported by Faulkner et al. (2009).

Fish are loaded aboard trucks and barges at Lower Granite, Little Goose, or Lower Monumental Dams on the Snake River or at McNary Dam on the Columbia River. These fish are transported past three to seven downstream dams. The effectiveness of fish transportation is evaluated in part by comparing smolt to adult return (SAR) ratios for transported and inriver migrants. The annual benefit of transportation is sometimes related to river conditions experienced by fish left to migrate through the hydropower system. In 2007, seasonal average survival of inriver migrant yearling Chinook and steelhead from the tailrace of Lower Granite Dam to the tailrace of Bonneville Dam was 59.7 and 36.4\%, respectively. In 2008, the survival estimates were slightly lower for yearling Chinook salmon (41.9) and higher for steelhead (45.8\%; Table 8).

We speculate that higher survival years for inriver migrants are associated increased flow volumes. In 2001 and 2004, two years characterized by extremely low river flows due to regional drought, survival probabilities for yearling Chinook salmon (27.9 and 39.5\%, respectively) were much lower than in other years. In 2008, flow volumes were generally lower-than-average prior to mid-May and higher-than-average from mid-May to mid-June. Similarly, survival probabilities for Snake River steelhead through the entire hydropower system downstream from Lower Granite Dam in 2008 
(45.8\%) were higher than in any year since 1998 (50.0\%). Again, though exceptionally low survival was estimated in 2001 for inriver migrant steelhead (4\%), this was a drought year during which most fish were transported.

Table 7. Weekly average survival percentages from the tailrace of McNary Dam to the tailrace of Bonneville Dam for yearling Chinook salmon and steelhead from Snake River sources, 2008. Total fish used in the survival estimates, weighted average survivals, and standard errors (SE) for each species are presented. Dashes indicate sample size was too small for estimates of survival.

\begin{tabular}{|c|c|c|c|c|c|c|c|}
\hline \multirow[b]{2}{*}{ Date } & \multirow[b]{2}{*}{$\mathrm{N}$} & \multicolumn{2}{|c|}{$\begin{array}{c}\text { McNary to } \\
\text { John Day Dam }\end{array}$} & \multicolumn{2}{|c|}{$\begin{array}{c}\text { John Day to } \\
\text { Bonneville Dam }\end{array}$} & \multicolumn{2}{|c|}{$\begin{array}{c}\text { McNary to } \\
\text { Bonneville Dam }\end{array}$} \\
\hline & & $\%$ & SE & $\%$ & SE & $\%$ & SE \\
\hline & \multicolumn{7}{|c|}{ Snake River yearling Chinook salmon } \\
\hline 27 Apr-03 May & 588 & 1.103 & 0.190 & 0.507 & 0.167 & 0.559 & 0.156 \\
\hline 04 Apr-10 May & 7,576 & 0.983 & 0.054 & 0.761 & 0.080 & 0.748 & 0.067 \\
\hline 11 May-17 May & 24,299 & 1.195 & 0.060 & 0.379 & 0.036 & 0.453 & 0.036 \\
\hline 18 May-24 May & 13,541 & 1.175 & 0.099 & 0.682 & 0.189 & 0.802 & 0.212 \\
\hline 25 May-31 May & 3,244 & 0.731 & 0.084 & NA & NA & NA & NA \\
\hline 01 Jun-07 Jun & 1,239 & 0.962 & 0.164 & 0.795 & 0.544 & 0.764 & 0.507 \\
\hline 08 Jun-14 Jun & 716 & 0.747 & 0.202 & 0.640 & 0.606 & 0.478 & 0.434 \\
\hline \multirow[t]{2}{*}{ Wt. Avg. } & 51,203 & 1.073 & 0.058 & 0.559 & 0.082 & 0.593 & 0.066 \\
\hline & \multicolumn{7}{|c|}{ Snake River steelhead } \\
\hline 20 Apr-26 Apr & 329 & 0.857 & 0.217 & 0.356 & 0.158 & 0.305 & 0.110 \\
\hline 27 Apr-03 May & 1612 & 0.942 & 0.100 & 0.706 & 0.198 & 0.665 & 0.173 \\
\hline 04 May-10 Мay & 4569 & 0.860 & 0.041 & 0.802 & 0.077 & 0.690 & 0.058 \\
\hline 11 May-17 May & 3729 & 1.101 & 0.104 & 0.654 & 0.142 & 0.720 & 0.140 \\
\hline 18 May-24 May & 2420 & 1.070 & 0.129 & 0.690 & 0.380 & 0.739 & 0.396 \\
\hline 25 May-31 May & 1280 & 1.704 & 0.351 & 0.367 & 0.255 & 0.625 & 0.415 \\
\hline 01 Jun-07 Jun & 844 & 0.906 & 0.138 & 0.492 & 0.226 & 0.446 & 0.194 \\
\hline Wt. Avg. & 14,783 & 0.949 & 0.066 & 0.743 & 0.045 & 0.671 & 0.034 \\
\hline
\end{tabular}




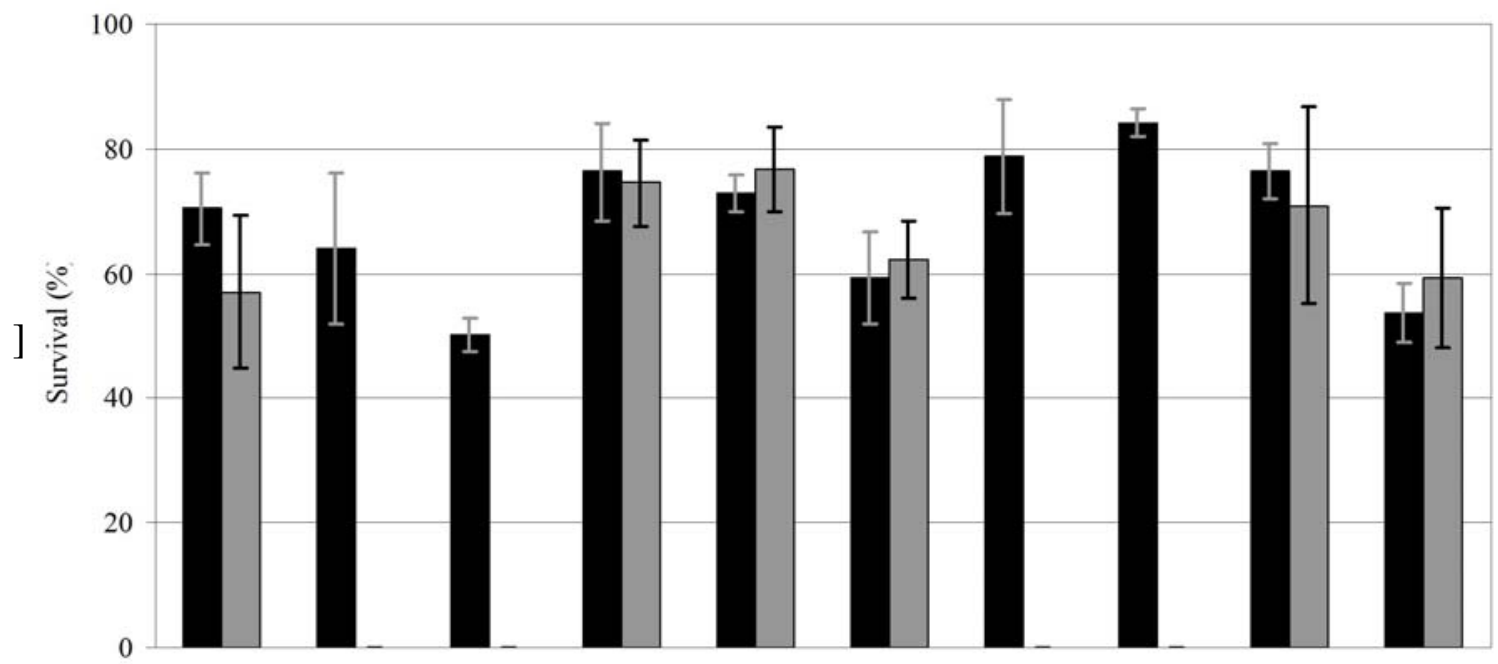

- Snake River $\square$ Mid-Columbia

Steelhead

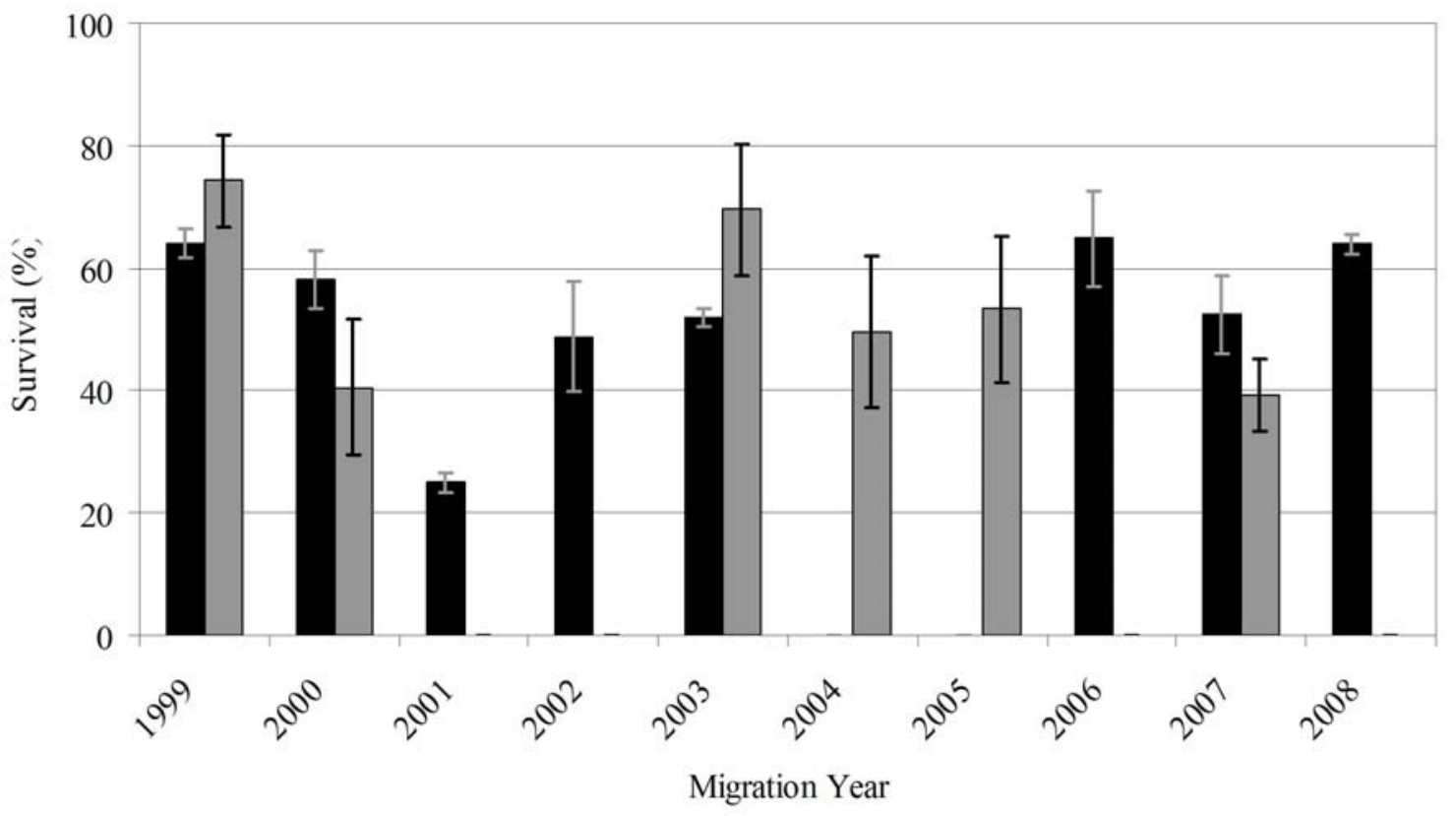

Figure 12. Weighted average annual survival probabilities and standard errors from the tailrace of McNary Dam to the tailrace of Bonneville Dam for yearling Chinook salmon and steelhead from the Snake and mid-Columbia Rivers, 1999-2008. 
Table 8. Weighted annual mean survival probabilities and standard errors from the tailrace of Lower Granite Dam to the tailrace of Bonneville Dam for yearling Chinook salmon and steelhead, 1998-2008.

\begin{tabular}{lllll}
\hline & \multicolumn{5}{c}{ Survival estimates } \\
\cline { 2 - 5 } Migration year & \multicolumn{5}{c}{ Yearling Chinook salmon } & Steelhead \\
\hline 19$)$ & 53.8 & SE & 50 & SE \\
1999 & 55.7 & 4.6 & 44 & 5.4 \\
2000 & 48.6 & 9.3 & 39.3 & 1.8 \\
2001 & 27.9 & 1.6 & 4.2 & 3.4 \\
2002 & 57.8 & 6 & 26.2 & 0.3 \\
2003 & 53.2 & 2.3 & 30.9 & 5 \\
2004 & 39.5 & 5 & $--*$ & 1.1 \\
2005 & 57.7 & 6.9 & $--*$ & $--*$ \\
2006 & 64.3 & 1.7 & 45.5 & $--*$ \\
2007 & 59.7 & 3.5 & 36.4 & 5.6 \\
2008 & 41.9 & 3.7 & 45.8 & 4.5 \\
\hline
\end{tabular}

* Sample size too small to estimate annual survival probability 


\section{REFERENCES}

Berggren, T., H. Franzoni, L. Basham, P. Wilson, H. Schaller, C. Petrosky, E. Weber, and R. Boyce. 2006. Comparative survival study (CCS) of PIT-tagged spring/summer Chinook and PIT-tagged summer steelhead. Report of the Fish Passage Center Comparative Survival Oversight Committee to the Bonneville Power Administration, Portland, Oregon.

Cormack, R. M. 1964. Estimates of survival from the sighting of marked animals. Biometrika, 51:429-438.

Faulkner, J. R., S. G. Smith, W. D. Muir, D. M. Marsh, and J. G. Williams. In press. Survival estimates for the passage of spring-migrating juvenile salmonids through Snake and Columbia River dams and reservoirs, 2007. Report of the National Marine Fisheries Service to the Bonneville Power Administration, Portland, Oregon.

Faulkner, J. R., S. G. Smith, W. D. Muir, D. M. Marsh, and J. G. Williams. 2007. Survival estimates for the passage of spring-migrating juvenile salmonids through Snake and Columbia River dams and reservoirs, 2006. Report of the National Marine Fisheries Service to the Bonneville Power Administration, Portland, Oregon.

Jolly, G. M. 1965. Explicit estimates from capture recapture data with both death and immigration stochastic model. Biometrika, 52: 225-247.

Ledgerwood, R. D. J. W. Ferguson, B. A. Ryan, E. M. Dawley, and E. P. Nunnallee. 2004. A surface trawl to detect migrating juvenile salmonids tagged with passive integrated transponder tags. North American Journal of Fisheries Management.

Ledgerwood, R. D., A. S. Cameron, B. P. Sandford, L. B. Way, and G. M. Matthews. 2005. Detection of PIT-tagged juvenile salmonids in the Columbia River estuary using a pair-trawl, 2002. Report of the National Marine Fisheries Service to the U.S. Army Corps of Engineers, Walla Walla, Washington.

Ledgerwood, R. D., A. S. Cameron, B. P. Sandford, L. B. Way, and G. M. Matthews. 2006. Detection of PIT-tagged juvenile salmonids in the Columbia River estuary using a pair-trawl, 2003-2004. Report of the National Marine Fisheries Service to the U.S. Army Corps of Engineers, Walla Walla, Washington. 
Ledgerwood, R. D., A. S. Cameron, B. P. Sandford, L. B. Way, and G. M. Matthews. 2007. Detection of PIT-tagged juvenile salmonids in the Columbia River estuary using a pair-trawl, 2005. Report of the National Marine Fisheries Service to the U.S. Army Corps of Engineers, Walla Walla, Washington

Magie, R. J., A. S. Cameron, R. D. Ledgerwood, B. P. Sandford, and G. M. Matthews. 2008. Detection of PIT-tagged juvenile salmonids in the Columbia River estuary using pair-trawls, 2006. Report of the National Marine Fisheries Service to the U.S. Army Corps of Engineers, Walla Walla, Washington

Magie, R. J., R. D. Ledgerwood, A. S. Cameron, M. S. Morris, B. P. Sandford, and G. M. Matthews. In press. Detection of PIT-tagged juvenile salmonids in the Columbia River estuary using pair-trawls, 2007. Report of the National Marine Fisheries Service to the U.S. Army Corps of Engineers, Walla Walla, Washington

Marsh, D. M., J. R. Harmon, N. N. Paasch, K. L. Thomas, K. W. McIntyre, B. P. Sandford, G. M. Matthews, and W. D. Muir. 2006. Transportation of juvenile salmonids on the Snake River, 2006: Final report for the 2003 wild spring/summer Chinook salmon juvenile migration. Report of the National Marine Fisheries Service to the U.S. Army Corps of Engineers, Walla Walla, Washington.

Muir, W. D., S. G. Smith, J. G. Williams, E. E. Hockersmith, and J. R. Skalski. 2001. Survival estimates for migrant yearling Chinook salmon and steelhead tagged with passive integrated transponders in the lower Snake and lower Columbia Rivers, 1993-1998. North American Journal of Fisheries Management 21:269-282.

Prentice, E. F., T. A. Flagg, and C. S. McCutcheon. 1990a. Electronic tags. American Fisheries Society Symposium 7:317-322.

Prentice, E. F., T. A. Flagg, C. S. McCutcheon, and D. F. Brastow. 1990b. PIT-tag monitoring systems for hydroelectric dams and fish hatcheries. American Fisheries Society Symposium 7:323-334.

Prentice, E. F., T. A. Flagg, C. S. McCutcheon, D. F. Brastow, and D. C. Cross. 1990c. Equipment, methods, and an automated data-entry station for PIT tagging. American Fisheries Society Symposium 7:335-340.

PSMFC (Pacific States Marine Fisheries Commission). 2008. The Columbia Basin PIT-Tag-Information System (PTAGIS). Online interactive database, Pacific States Marine Fisheries Commission, Gladstone, Oregon (available via the internet at www.PSMFC.org/pittag). 
Seber, G. A. F. 1965. A Note on the Multiple Recapture Census. Biometrica, 52:249-259.

Skalski, J. R., S. G. Smith, R. N. Iwamoto, J. G. Williams, and A. Hoffmann. 1998. Use of passive integrated transponder tags to estimate survival of migrant juvenile salmonids in the Snake and Columbia Rivers. Canadian Journal of Fisheries and Aquatic Sciences 55:1484-1493.

Stein, C. D. Marvin, J. Tenney, and N. Gruman, editors. 2004. 2004 PIT tag specification document. Report of the Pacific States Marine Fisheries Commission to the PIT tag Technical Steering Committee. Gladstone, Oregon (available via the internet at www.psmfc.org/pittag).

Williams, J. G., S. G. Smith, and W. D. Muir. 2001. Survival estimates for downstream migrant yearling juvenile salmonids through the Snake and Columbia River hydropower system, 1966 to 1980 and 1993 to 1999. North American Journal of Fisheries Management 21:310-317.

Zabel, R. W. and J. G. Williams. 2002. Selective mortality for fish length and migrational timing in Chinook salmon: what is the role of human disturbance? Ecological Applications 12:173-183. 


\section{APPENDIX}

\section{Data Tables}

Appendix Table 1. Configuration of ST tags on the tape measure used to test antenna performance in 2008.

\begin{tabular}{|c|c|c|c|}
\hline $\begin{array}{c}\text { Position on } \\
\text { tape measure (ft) }\end{array}$ & Orientation $\left(^{\circ}\right)$ & $\begin{array}{c}\text { Distance from } \\
\text { previous tag }(\mathrm{ft})^{\mathbf{a}}\end{array}$ & PIT-tag code $\mathrm{e}^{\mathbf{b}}$ \\
\hline 17 & 0 & 0 & 3D9.1BF22F5437 \\
\hline 19 & 0 & 2 & 3D9.1BF1A73554 \\
\hline 21 & 0 & $2^{c}$ & 3D9.1BF1A723D6 \\
\hline 23 & 45 & $2^{c}$ & 3D9.1BF1A6BBD5 \\
\hline 25 & 45 & 2 & 3D9.1BF1F8B9A4 \\
\hline 28 & 0 & 3 & 3D9.1BF1A6BE89 \\
\hline 31 & 0 & $3^{c}$ & 3D9.1BF1F7DDEA \\
\hline 34 & 0 & $3^{c}$ & 3D9.1BF1A1E4AF \\
\hline 37 & 45 & $3^{c}$ & 3D9.1BF1CF5597 \\
\hline 40 & 45 & $3^{c}$ & 3D9.1BF1E73089 \\
\hline 43 & 45 & 3 & 3D9.1BF1F81373 \\
\hline 45 & 0 & 2 & 3D9.1BF1F7D25F \\
\hline 47 & 0 & $2^{c}$ & 3D9.1BF1F7DC5C \\
\hline 49 & 0 & 2 & 3D9.1BF1F7D8EA \\
\hline 50 & 0 & 1 & 3D9.1BF1A71E13 \\
\hline 51 & 0 & $1^{\mathrm{c}}$ & 3D9.1BF1A1CD75 \\
\hline 52 & 0 & 1 & 3D9.1BF1F7CDF7 \\
\hline 55 & 0 & 3 & 3D9.1BF1F8F242 \\
\hline 58 & 0 & 3 & 3D9.1BF1A7A629 \\
\hline 59 & 0 & 1 & 3D9.1BF1F85701 \\
\hline 62 & 0 & 3 & 3D9.1BF1A72BFD \\
\hline 63 & 0 & 1 & 3D9.1BF1F8CAB0 \\
\hline 66 & 0 & 3 & 3D9.1BF1F8BBEB \\
\hline 69 & 45 & 3 & 3D9.1BF1F7CD88 \\
\hline 70 & 45 & 1 & 3D9.1BF1A9ADDC \\
\hline 72 & 0 & 2 & 3D9.1BF1F7268D \\
\hline 73 & 0 & 1 & 3D9.1BF1A972D5 \\
\hline 75 & 0 & 2 & 3D9.1BF1A6B38B \\
\hline 77 & 0 & 2 & 3D9.1BF1F81389 \\
\hline 81 & 0 & 4 & 3D9.1BF1A98D9E \\
\hline
\end{tabular}


Appendix Table 1. Continued.

\begin{tabular}{cccc}
\hline $\begin{array}{c}\text { Position on } \\
\text { tape measure }(\mathrm{ft})\end{array}$ & Orientation $\left(^{\circ}\right)$ & $\begin{array}{c}\text { Distance from } \\
\text { previous tag }(\mathrm{ft})^{\mathrm{a}}\end{array}$ & PIT-tag code $^{\mathrm{b}}$ \\
\hline 83 & 0 & 2 & 3D9.1BF1A7885E \\
85 & 0 & 2 & 3D9.1BF1A73F1E \\
88 & 45 & 3 & 3D9.1BF1A9B578 \\
89 & 45 & 1 & 3D9.1BF1A9919F \\
91 & 45 & 2 & 3D9.1BF1A78FC4 \\
92 & 45 & 1 & 3D9.1BF1A76D70 \\
94 & 45 & 2 & 3D9.1BF1A9C00C \\
96 & 45 & 2 & 3D9.1BF1CF51C6 \\
100 & 45 & 4 & 3D9.1BF1A9C20F \\
102 & 45 & 2 & 3D9.1BF1F7C65E \\
104 & 45 & $2^{\mathbf{c}}$ & 3D9.1BF1A77453 \\
106 & 0 & $2^{\mathbf{c}}$ & 3D9.1BF1A6C70C \\
108 & 0 & $2^{\mathbf{c}}$ & 3D9.1BF1A1D513 \\
110 & 0 & $2^{\mathbf{c}}$ & 3D9.1BF1A6C4CF \\
112 & 0 & $2^{\mathbf{c}}$ & 3D9.1BF1A98396 \\
114 & 45 & $2^{\mathbf{c}}$ & 3D9.1BF1A1D0F8 \\
116 & 45 & $2^{\mathbf{c}}$ & 3D9.1BF22BF651 \\
118 & 45 & $2^{\mathbf{c}}$ & 3D9.1BF1F8DA09 \\
120 & 45 & 2 & 3D9.1BF22A8198 \\
125 & 0 & 5 & 3D9.1BF1A9953C \\
\hline
\end{tabular}

${ }^{\text {a }}$ Distance from previous tag as measured in the direction from 17 to $125 \mathrm{ft}$.

b PIT-tags were tested after each antenna evaluation with a hand-held reader and replaced as needed.

c Target tag defined as having same spacing from adjacent tags when tape is pulled through the antenna in either direction. These analyses can not be compared with those of previous years. 
Appendix Table 2. Configuration of SST tags on the tape measure used to test antenna performance in 2008.

\begin{tabular}{|c|c|c|c|}
\hline $\begin{array}{l}\text { Position on tape } \\
\text { measure }(\mathrm{ft})\end{array}$ & Orientation & $\begin{array}{c}\text { Distance from } \\
\text { previous tag }(\mathrm{ft})^{\mathbf{a}}\end{array}$ & PIT-tag code ${ }^{\mathbf{b}}$ \\
\hline 17 & 0 & 0 & 3D9.257C6C560F \\
\hline 19 & 0 & 2 & 3D9.257C6BF8D9 \\
\hline 21 & 0 & $2^{c}$ & 3D9.257C594C2B \\
\hline 23 & 45 & $2^{c}$ & 3D9.257C5E544A \\
\hline 25 & 45 & 2 & 3D9.257C6C4183 \\
\hline 28 & 0 & 3 & 3D9.1C2061C9DB \\
\hline 31 & 0 & $3^{c}$ & 3D9.257C6BFE58 \\
\hline 34 & 0 & $3^{c}$ & 3D9.257C6C3DB9 \\
\hline 37 & 45 & $3^{c}$ & 3D9.257C6C4E5C \\
\hline 40 & 45 & $3^{c}$ & 3D9.257C6C27D2 \\
\hline 43 & 45 & 3 & 3D9.257C6C0AEB \\
\hline 45 & 0 & 2 & 3D9.257C6BFE83 \\
\hline 47 & 0 & $2^{c}$ & 3D9.257C6C00BB \\
\hline 49 & 0 & 2 & 3D9.257C6C4FF9 \\
\hline 50 & 0 & 1 & 3D9.257C6C287B \\
\hline 51 & 0 & $1^{\mathrm{c}}$ & 3D9.257C6C67D2 \\
\hline 52 & 0 & 1 & 3D9.257C6C0723 \\
\hline 55 & 0 & 3 & 3D9.257C6C4C9A \\
\hline 58 & 0 & 3 & 3D9.257C6C33B5 \\
\hline 59 & 0 & 1 & 3D9.257C6C68F9 \\
\hline 62 & 0 & 3 & 3D9.257C6C02C5 \\
\hline 63 & 0 & 1 & 3D9.257C6C32A4 \\
\hline 66 & 0 & 3 & 3D9.1C2C5DD932 \\
\hline 69 & 45 & 3 & 3D9.257C6C4DC2 \\
\hline 70 & 45 & 1 & 3D9.257C6BFDF2 \\
\hline 72 & 0 & 2 & 3D9.257C6C29B8 \\
\hline 73 & 0 & 1 & 3D9.257C6C51D3 \\
\hline 75 & 0 & 2 & 3D9.257C6C395F \\
\hline 77 & 0 & 2 & 3D9.257C6C839E \\
\hline 81 & 0 & 4 & 3D9.257C6C4CE8 \\
\hline 83 & 0 & 2 & 3D9.257C6C3570 \\
\hline 85 & 0 & 2 & 3D9.257C6C0B80 \\
\hline 88 & 45 & 3 & 3D9.257C6C47B7 \\
\hline
\end{tabular}


Appendix Table 2. Continued.

\begin{tabular}{lccc}
\hline $\begin{array}{l}\text { Position on tape } \\
\text { measure (ft) }\end{array}$ & Orientation & $\begin{array}{c}\text { Distance from } \\
\text { previous tag }(\mathrm{ft})^{\mathbf{a}}\end{array}$ & PIT-tag code $^{\mathbf{b}}$ \\
\hline 89 & 45 & 1 & 3D9.257C6BFA2B \\
91 & 45 & 2 & 3D9.257C5E5447 \\
92 & 45 & 1 & 3D9.257C6C332F \\
94 & 45 & 2 & 3D9.257C6C4AE5 \\
96 & 45 & 2 & 3D9.257C6C18B0 \\
100 & 45 & 4 & 3D9.257C6C35E1 \\
102 & 45 & 2 & 3D9.257C6C26FE \\
104 & 45 & $2^{\mathbf{c}}$ & 3D9.257C6C4249 \\
106 & 0 & $2^{\mathbf{c}}$ & 3D9.257C6C0A71 \\
108 & 0 & $2^{\mathbf{c}}$ & 3D9.257C6C00F6 \\
110 & 0 & $2^{\mathbf{c}}$ & 3D9.257C6C4A84 \\
112 & 0 & $2^{\mathbf{c}}$ & 3D9.257C6C2AA7 \\
114 & 45 & $2^{\mathbf{c}}$ & 3D9.257C5E6417 \\
116 & 45 & $2^{\mathbf{c}}$ & 3D9.257C6BF89B \\
118 & 45 & $2^{\mathbf{c}}$ & 3D9.257C6C0B06 \\
120 & 45 & 2 & 3D9.257C6C0602 \\
125 & 0 & 5 & 3D9.257C5E61BF \\
\hline
\end{tabular}

${ }^{\text {a }}$ Distance from previous tag as measured in the direction from 17 to $125 \mathrm{ft}$.

b PIT-tags were tested after each antenna evaluation with a hand-held reader and replaced as needed.

${ }^{\mathbf{c}}$ Target tag defined as having same spacing from adjacent tags when tape is pulled through the antenna in either direction. These analyses can not be compared with those of previous years. 
Appendix Table 3. Detections on the matrix, cylindrical, and both systems during tandem sampling, 2008.

\begin{tabular}{|c|c|c|c|c|c|c|c|c|c|c|c|c|}
\hline \multirow[b]{3}{*}{ Date } & \multicolumn{12}{|c|}{ Tandem sampling detections } \\
\hline & \multicolumn{4}{|c|}{ Matrix system } & \multicolumn{4}{|c|}{ Cylindrical system } & \multicolumn{4}{|c|}{ Detected on both systems } \\
\hline & Unknown & Chinook & Steelhead & Sockeye & Unknown & Chinook & Steelhead & Sockeye & Unknown & Chinook & Steelhead & Sockeye \\
\hline 13 May & 1 & 32 & 108 & 0 & 3 & 24 & 34 & 0 & 0 & 4 & 6 & 0 \\
\hline 14 May & 0 & 101 & 339 & 1 & 1 & 77 & 109 & 0 & 0 & 16 & 27 & 0 \\
\hline 15 May & 0 & 40 & 94 & 0 & 0 & 42 & 49 & 0 & 0 & 10 & 13 & 0 \\
\hline Totals & 1 & 173 & 541 & 1 & 4 & 143 & 192 & 0 & 0 & 30 & 46 & 0 \\
\hline \multicolumn{13}{|c|}{ Overall totals (all species combined) } \\
\hline & \multicolumn{4}{|c|}{716} & \multicolumn{4}{|c|}{339} & \multicolumn{4}{|c|}{76} \\
\hline
\end{tabular}


Appendix Table 4. Combined daily total of impinged fish the cylindrical trawl, shoreline sampler and matrix system, in the upper and lower Columbia River estuary, 2008.

\begin{tabular}{|c|c|c|c|c|c|}
\hline \multirow[b]{2}{*}{ Date } & \multicolumn{2}{|c|}{ Chinook salmon } & \multirow[b]{2}{*}{ Coho salmon } & \multirow[b]{2}{*}{ Steelhead } & \multirow[b]{2}{*}{ Sockeye } \\
\hline & Yearling & Subyearling & & & \\
\hline 7 Mar & 0 & 0 & & & \\
\hline $8 \mathrm{Mar}$ & -- & -- & -- & -- & -- \\
\hline $9 \mathrm{Mar}$ & -- & -- & -- & -- & -- \\
\hline $10 \mathrm{Mar}$ & 0 & 0 & 0 & 0 & 0 \\
\hline $11 \mathrm{Mar}$ & -- & -- & -- & -- & -- \\
\hline $12 \mathrm{Mar}$ & 0 & 0 & 0 & 0 & 0 \\
\hline $13 \mathrm{Mar}$ & -- & -- & -- & -- & -- \\
\hline $14 \mathrm{Mar}$ & 0 & 0 & 0 & 0 & 0 \\
\hline $15 \mathrm{Mar}$ & -- & -- & -- & -- & -- \\
\hline $16 \mathrm{Mar}$ & -- & -- & -- & -- & -- \\
\hline 17 Mar & 0 & 0 & 0 & 0 & 0 \\
\hline 18 Mar & - & - & - & - & - \\
\hline 19 Mar & 0 & 0 & 0 & 0 & 0 \\
\hline $20 \mathrm{Mar}$ & -- & -- & -- & -- & -- \\
\hline $21 \mathrm{Mar}$ & 0 & 0 & 0 & 0 & 0 \\
\hline $22 \mathrm{Mar}$ & -- & -- & -- & -- & -- \\
\hline $23 \mathrm{Mar}$ & -- & -- & -- & -- & -- \\
\hline $24 \mathrm{Mar}$ & 0 & 0 & 0 & 0 & 0 \\
\hline 25 Mar & -- & -- & -- & -- & -- \\
\hline 26 Mar & 0 & 0 & 0 & 0 & 0 \\
\hline 27 Mar & -- & -- & -- & -- & -- \\
\hline $28 \mathrm{Mar}$ & 0 & 0 & 0 & 0 & 0 \\
\hline 29 Mar & -- & -- & -- & -- & -- \\
\hline 30 Mar & -- & -- & -- & -- & -- \\
\hline 31 Mar & -- & -- & -- & -- & -- \\
\hline $1 \mathrm{Apr}$ & -- & -- & -- & -- & -- \\
\hline $2 \mathrm{Apr}$ & 0 & 0 & 0 & 0 & 0 \\
\hline $3 \mathrm{Apr}$ & 0 & 0 & 0 & 0 & 0 \\
\hline $4 \mathrm{Apr}$ & 0 & 0 & 0 & 0 & 0 \\
\hline $5 \mathrm{Apr}$ & -- & -- & -- & -- & -- \\
\hline $6 \mathrm{Apr}$ & -- & -- & -- & -- & -- \\
\hline $7 \mathrm{Apr}$ & 0 & 0 & 0 & 0 & 0 \\
\hline $8 \mathrm{Apr}$ & -- & -- & -- & -- & -- \\
\hline $9 \mathrm{Apr}$ & 0 & 0 & 0 & 0 & 0 \\
\hline 10 Apr & 0 & 0 & 0 & 0 & 0 \\
\hline 11 Apr & 0 & 0 & 0 & 0 & 0 \\
\hline 12 Apr & -- & -- & -- & -- & -- \\
\hline $13 \mathrm{Apr}$ & -- & -- & -- & -- & -- \\
\hline 14 Apr & 0 & 0 & 0 & 0 & 0 \\
\hline $15 \mathrm{Apr}$ & 0 & 0 & 0 & 0 & 0 \\
\hline 16 Apr & 1 & 0 & 0 & 0 & 0 \\
\hline $17 \mathrm{Apr}$ & -- & -- & -- & -- & -- \\
\hline 18 Apr & 0 & 0 & 0 & 0 & 0 \\
\hline $19 \mathrm{Apr}$ & -- & -- & -- & -- & -- \\
\hline $20 \mathrm{Apr}$ & -- & -- & -- & -- & -- \\
\hline 21 Apr & 0 & 0 & 0 & 0 & 0 \\
\hline 22 Apr & -- & -- & -- & -- & -- \\
\hline $23 \mathrm{Apr}$ & 0 & 0 & 0 & 0 & 0 \\
\hline 24 Apr & -- & -- & -- & -- & -- \\
\hline $25 \mathrm{Apr}$ & 0 & 0 & 0 & 0 & 0 \\
\hline 26 Apr & 0 & 0 & 0 & 0 & 0 \\
\hline $27 \mathrm{Apr}$ & -- & -- & -- & -- & -- \\
\hline $28 \mathrm{Apr}$ & 0 & 0 & 0 & 0 & 0 \\
\hline $29 \mathrm{Apr}$ & 0 & 0 & 0 & 0 & 0 \\
\hline $30 \mathrm{Apr}$ & 3 & 0 & 0 & 1 & 0 \\
\hline
\end{tabular}


Appendix Table 4. Continued.

\begin{tabular}{|c|c|c|c|c|c|}
\hline \multirow[b]{2}{*}{ Date } & \multicolumn{2}{|c|}{ Chinook salmon } & \multirow[b]{2}{*}{ Coho salmon } & \multirow[b]{2}{*}{ Steelhead } & \multirow[b]{2}{*}{ Sockeye } \\
\hline & Yearling & Subyearling & & & \\
\hline 1 May & 0 & 0 & 0 & 0 & 0 \\
\hline 2 May & 9 & 1 & 1 & 2 & \\
\hline 3 May & 1 & 0 & 0 & 0 & 0 \\
\hline 4 May & 2 & 0 & 0 & 0 & 0 \\
\hline 5 May & 1 & 0 & 0 & 0 & 0 \\
\hline 6 May & 2 & 0 & 0 & 0 & 0 \\
\hline 7 May & 1 & 0 & 0 & 0 & 0 \\
\hline 8 May & 3 & 0 & 1 & 0 & 0 \\
\hline 9 May & 4 & 0 & 0 & 1 & 0 \\
\hline 10 May & 3 & 0 & 1 & 0 & 0 \\
\hline 11 May & 3 & 0 & 1 & 0 & 0 \\
\hline 12 May & 4 & 0 & 1 & 1 & 0 \\
\hline 13 May & 2 & 0 & 0 & 0 & 0 \\
\hline 14 May & 14 & 2 & 3 & 2 & 0 \\
\hline 15 May & 4 & 0 & 0 & 1 & 0 \\
\hline 16 May & 3 & 1 & 0 & 0 & 0 \\
\hline 17 May & 15 & 0 & 4 & 3 & 0 \\
\hline 18 May & 4 & 1 & 1 & 1 & 0 \\
\hline 19 May & 3 & 0 & 0 & 1 & 0 \\
\hline 20 May & 0 & 0 & 0 & 0 & 0 \\
\hline 21 May & 8 & 0 & 1 & 1 & 0 \\
\hline 22 May & 6 & 0 & 1 & 0 & 0 \\
\hline 23 May & 4 & 0 & 1 & 0 & 0 \\
\hline 24 May & 1 & 0 & 0 & 0 & 0 \\
\hline 25 May & 4 & 0 & 0 & 1 & 0 \\
\hline 26 May & 2 & 0 & 0 & 0 & 0 \\
\hline 27 May & 0 & 0 & 0 & 0 & 0 \\
\hline 28 May & 2 & 0 & 0 & 0 & 0 \\
\hline 29 May & 2 & 0 & 0 & 0 & 0 \\
\hline 30 May & 2 & 0 & 0 & 0 & 0 \\
\hline 31 May & 5 & 1 & 1 & 1 & 0 \\
\hline 1 Jun & 0 & 0 & 0 & 0 & 0 \\
\hline 2 Jun & 1 & 0 & 0 & 0 & 0 \\
\hline 3 Jun & 1 & 0 & 0 & 0 & 0 \\
\hline 4 Jun & 3 & 0 & 1 & 0 & 0 \\
\hline 5 Jun & 0 & 0 & 0 & 0 & 0 \\
\hline 6 Jun & 1 & 0 & 0 & 0 & 0 \\
\hline 7 Jun & 6 & 1 & 1 & 1 & 0 \\
\hline 8 Jun & 0 & 0 & 0 & 0 & 0 \\
\hline 9 Jun & 2 & 0 & 0 & 0 & 0 \\
\hline 10 Jun & 2 & 0 & 0 & 0 & 0 \\
\hline 11 Jun & 0 & 0 & 0 & 0 & 0 \\
\hline 12 Jun & 1 & 0 & 0 & 0 & 0 \\
\hline 13 Jun & 0 & 0 & 0 & 0 & 0 \\
\hline 14 Jun & 0 & 0 & 0 & 0 & 0 \\
\hline 15 Jun & 0 & 0 & 0 & 0 & 0 \\
\hline 16 Jun & 0 & 0 & 0 & 0 & 0 \\
\hline 17 Jun & 0 & 0 & 0 & 0 & 0 \\
\hline 18 Jun & 0 & 0 & 0 & 0 & 0 \\
\hline 19 Jun & 0 & 0 & 0 & 0 & 0 \\
\hline 20 Jun & 0 & 0 & 0 & 0 & 0 \\
\hline 21 Jun & 1 & 0 & 0 & 0 & 0 \\
\hline 22 Jun & 0 & 0 & 0 & 0 & 0 \\
\hline 23 Jun & 0 & 0 & 0 & 0 & 0 \\
\hline 24 Jun & 0 & 0 & 0 & 0 & 0 \\
\hline 25 Jun & 0 & 0 & 0 & 0 & 0 \\
\hline 26 Jun & 0 & 0 & 0 & 0 & 0 \\
\hline
\end{tabular}


Appendix Table 4. Continued.

\begin{tabular}{|c|c|c|c|c|c|}
\hline \multirow[b]{2}{*}{ Date } & \multicolumn{2}{|c|}{ Chinook salmon } & \multirow[b]{2}{*}{ Coho salmon } & \multirow[b]{2}{*}{ Steelhead } & \multirow[b]{2}{*}{ Sockeve } \\
\hline & Yearling & Subyearling & & & \\
\hline 27 Jun & 0 & 0 & 0 & 0 & 0 \\
\hline 28 Jun & 0 & 0 & 0 & 0 & 0 \\
\hline 29 Jun & -- & -- & -- & -- & -- \\
\hline 30 Jun & 0 & 0 & 0 & 0 & 0 \\
\hline $1 \mathrm{Jul}$ & 0 & 0 & 0 & 0 & 0 \\
\hline $2 \mathrm{Jul}$ & 1 & 0 & 0 & 0 & 0 \\
\hline $3 \mathrm{Jul}$ & 0 & 0 & 0 & 0 & 0 \\
\hline $4 \mathrm{Jul}$ & -- & -- & -- & -- & -- \\
\hline $5 \mathrm{Jul}$ & 1 & 0 & 0 & 0 & 0 \\
\hline $6 \mathrm{Jul}$ & -- & -- & -- & -- & -- \\
\hline $7 \mathrm{Jul}$ & 0 & 0 & 0 & 0 & 0 \\
\hline $8 \mathrm{Jul}$ & 1 & 0 & 0 & 0 & 0 \\
\hline $9 \mathrm{Jul}$ & 0 & 0 & 0 & 0 & 0 \\
\hline $10 \mathrm{Jul}$ & -- & -- & -- & -- & -- \\
\hline $11 \mathrm{Jul}$ & 0 & 0 & 0 & 0 & 0 \\
\hline $12 \mathrm{Jul}$ & 0 & 0 & 0 & 0 & 0 \\
\hline $13 \mathrm{Jul}$ & -- & -- & -- & -- & -- \\
\hline $14 \mathrm{Jul}$ & 1 & 0 & 0 & 0 & 0 \\
\hline $15 \mathrm{Jul}$ & 0 & 0 & 0 & 0 & 0 \\
\hline $16 \mathrm{Jul}$ & 0 & 0 & 0 & 0 & 0 \\
\hline $17 \mathrm{Jul}$ & -- & -- & -- & -- & -- \\
\hline $18 \mathrm{Jul}$ & 0 & 0 & 0 & 0 & 0 \\
\hline $19 \mathrm{Jul}$ & 0 & 0 & 0 & 0 & 0 \\
\hline $20 \mathrm{Jul}$ & 0 & 0 & 0 & 0 & 0 \\
\hline $21 \mathrm{Jul}$ & -- & -- & -- & -- & -- \\
\hline $22 \mathrm{Jul}$ & 0 & 0 & 0 & 0 & 0 \\
\hline $23 \mathrm{Jul}$ & 0 & 0 & 0 & 0 & 0 \\
\hline $24 \mathrm{Jul}$ & -- & -- & -- & -- & -- \\
\hline $25 \mathrm{Jul}$ & 0 & 0 & 0 & 0 & 0 \\
\hline $26 \mathrm{Jul}$ & 4 & 2 & 1 & 1 & 0 \\
\hline $27 \mathrm{Jul}$ & -- & - & - & -- & -- \\
\hline $28 \mathrm{Jul}$ & 3 & 0 & 0 & 0 & 0 \\
\hline $29 \mathrm{Jul}$ & 0 & 0 & 0 & 0 & 0 \\
\hline $30 \mathrm{Jul}$ & 0 & 0 & 0 & 0 & 0 \\
\hline $31 \mathrm{Jul}$ & -- & -- & -- & -- & -- \\
\hline 1 Aug & 0 & 0 & 0 & 0 & 0 \\
\hline 2 Aug & 0 & 0 & 0 & 0 & 0 \\
\hline 3 Aug & -- & -- & -- & -- & -- \\
\hline 4 Aug & 4 & 0 & 0 & 1 & 0 \\
\hline 5 Aug & 0 & 0 & 0 & 0 & 0 \\
\hline 6 Aug & 0 & 0 & 0 & 0 & 0 \\
\hline 7 Aug & -- & -- & -- & -- & -- \\
\hline 8 Aug & 0 & 0 & 0 & 0 & 0 \\
\hline 9 Aug & -- & -- & -- & -- & -- \\
\hline 10 Aug & -- & -- & -- & -- & -- \\
\hline 11 Aug & 0 & 0 & 0 & 0 & 0 \\
\hline 12 Aug & 0 & 0 & 0 & 0 & 0 \\
\hline 13 Aug & 0 & 0 & 0 & 0 & 0 \\
\hline 14 Aug & 0 & 0 & 0 & 0 & 0 \\
\hline 15 Aug & 0 & 0 & 0 & 0 & 0 \\
\hline 16 Aug & -- & -- & -- & -- & -- \\
\hline 17 Aug & -- & -- & -- & -- & -- \\
\hline 18 Aug & 0 & 0 & 0 & 0 & 0 \\
\hline 19 Aug & -- & -- & -- & -- & -- \\
\hline 20 Aug & 1 & 0 & 0 & 0 & 0 \\
\hline Total & 152 & 9 & 20 & 19 & 0 \\
\hline
\end{tabular}


Appendix Table 5. Detections in the Columbia River estuary of PIT-tagged juvenile Chinook salmon and steelhead previously detected at Bonneville Dam, 2008. The juvenile bypass system operated 3 Mar-18 Dec and the corner collector operated 6 Mar-2 Sep at Bonneville Dam; trawl operation 7 Mar-20 Aug, intensive sampling 30 Apr-14 Jun. Totals for the entire season are shown, including all release sites.

\begin{tabular}{|c|c|c|c|c|c|c|}
\hline \multirow{2}{*}{$\begin{array}{l}\text { Detection date } \\
\text { at } \\
\text { Bonneville Dam }\end{array}$} & \multicolumn{2}{|c|}{ Bonneville Dam detections } & \multicolumn{4}{|c|}{ Jones Beach detections } \\
\hline & $\begin{array}{c}\text { Chinook } \\
\text { salmon (n) }\end{array}$ & $\begin{array}{l}\text { Steelhead } \\
\text { (n) }\end{array}$ & $\begin{array}{c}\text { Chinook } \\
\text { salmon (n) }\end{array}$ & $\begin{array}{l}\text { Steelhead } \\
\text { (n) }\end{array}$ & $\begin{array}{c}\text { Chinook } \\
\text { salmon (\%) }\end{array}$ & $\begin{array}{c}\text { Steelhead } \\
\text { (\%) }\end{array}$ \\
\hline 16 Feb-6 Mar & 9 & 0 & 0 & -- & 0.00 & -- \\
\hline 07 Mar & 120 & 0 & 1 & -- & 0.83 & -- \\
\hline $08 \mathrm{Mar}$ & 192 & 0 & 1 & -- & 0.52 & -- \\
\hline 09 Mar & 141 & 0 & 0 & -- & 0.00 & -- \\
\hline 10 Mar & 41 & 0 & 0 & -- & 0.00 & -- \\
\hline $11 \mathrm{Mar}$ & 16 & 1 & 0 & 0 & 0.00 & 0.00 \\
\hline $12 \mathrm{Mar}$ & 12 & 0 & 0 & -- & 0.00 & -- \\
\hline $13 \mathrm{Mar}$ & 10 & 0 & 0 & -- & 0.00 & -- \\
\hline $14 \mathrm{Mar}$ & 0 & 0 & -- & -- & -- & -- \\
\hline 15 Mar & 2 & 0 & 0 & -- & 0.00 & -- \\
\hline $16 \mathrm{Mar}$ & 2 & 0 & 0 & -- & 0.00 & -- \\
\hline $17 \mathrm{Mar}$ & 2 & 0 & 0 & -- & 0.00 & -- \\
\hline $18 \mathrm{Mar}$ & 3 & 0 & 0 & -- & 0.00 & -- \\
\hline 19 Mar & 2 & 0 & 0 & -- & 0.00 & -- \\
\hline $20 \mathrm{Mar}$ & 1 & 0 & 0 & -- & 0.00 & -- \\
\hline $21 \mathrm{Mar}$ & 2 & 0 & 0 & -- & 0.00 & -- \\
\hline 22 Mar & 0 & 0 & -- & -- & -- & -- \\
\hline 23 Mar & 0 & 0 & -- & -- & -- & -- \\
\hline $24 \mathrm{Mar}$ & 1 & 0 & 0 & -- & 0.00 & -- \\
\hline 25 Mar & 1 & 0 & 0 & -- & 0.00 & -- \\
\hline 26 Mar & 1 & 0 & 0 & -- & 0.00 & -- \\
\hline 27 Mar & 1 & 0 & 0 & -- & 0.00 & -- \\
\hline $28 \mathrm{Mar}$ & 1 & 1 & 0 & 0 & 0.00 & 0.00 \\
\hline 29 Mar & 0 & 0 & -- & -- & -- & -- \\
\hline 30 Mar & 0 & 0 & -- & -- & -- & -- \\
\hline 31 Mar & 2 & 1 & 0 & 0 & 0.00 & 0.00 \\
\hline $01 \mathrm{Apr}$ & 0 & 0 & -- & -- & -- & -- \\
\hline $02 \mathrm{Apr}$ & 3 & 0 & 0 & -- & 0.00 & -- \\
\hline $03 \mathrm{Apr}$ & 1 & 3 & 0 & 0 & 0.00 & 0.00 \\
\hline $04 \mathrm{Apr}$ & 3 & 0 & 0 & -- & 0.00 & -- \\
\hline $05 \mathrm{Apr}$ & 3 & 2 & 0 & 0 & 0.00 & 0.00 \\
\hline $06 \mathrm{Apr}$ & 4 & 2 & 0 & 0 & 0.00 & 0.00 \\
\hline $07 \mathrm{Apr}$ & 1 & 10 & 0 & 0 & 0.00 & 0.00 \\
\hline $08 \mathrm{Apr}$ & 1 & 7 & 0 & 0 & 0.00 & 0.00 \\
\hline 09 Apr & 0 & 3 & -- & 0 & -- & 0.00 \\
\hline $10 \mathrm{Apr}$ & 2 & 2 & 0 & 0 & 0.00 & 0.00 \\
\hline $11 \mathrm{Apr}$ & 55 & 2 & 0 & 0 & 0.00 & 0.00 \\
\hline $12 \mathrm{Apr}$ & 115 & 3 & 0 & 0 & 0.00 & 0.00 \\
\hline $13 \mathrm{Apr}$ & 124 & 3 & 0 & 0 & 0.00 & 0.00 \\
\hline $14 \mathrm{Apr}$ & 71 & 7 & 1 & 0 & 1.41 & 0.00 \\
\hline 15 Apr & 85 & 6 & 1 & 0 & 1.18 & 0.00 \\
\hline $16 \mathrm{Apr}$ & 83 & 2 & 0 & 0 & 0.00 & 0.00 \\
\hline
\end{tabular}


Appendix Table 5. Continued.

\begin{tabular}{|c|c|c|c|c|c|c|}
\hline \multirow{2}{*}{$\begin{array}{l}\text { Detection date } \\
\text { at } \\
\text { Bonneville Dam }\end{array}$} & \multicolumn{2}{|c|}{ Bonneville Dam detections } & \multicolumn{4}{|c|}{ Jones Beach detections } \\
\hline & $\begin{array}{c}\text { Chinook } \\
\text { salmon (n) }\end{array}$ & $\begin{array}{l}\text { Steelhead } \\
\text { (n) }\end{array}$ & $\begin{array}{l}\text { Chinook } \\
\text { salmon (n) }\end{array}$ & $\begin{array}{l}\text { Steelhead } \\
\text { (n) }\end{array}$ & $\begin{array}{c}\text { Chinook } \\
\text { salmon (\%) }\end{array}$ & $\begin{array}{c}\text { Steelhead } \\
\text { (\%) }\end{array}$ \\
\hline $17 \mathrm{Apr}$ & 65 & 8 & 1 & 0 & 1.54 & 0.00 \\
\hline $18 \mathrm{Apr}$ & 88 & 6 & 0 & 0 & 0.00 & 0.00 \\
\hline 19 Apr & 104 & 4 & 0 & 0 & 0.00 & 0.00 \\
\hline $20 \mathrm{Apr}$ & 126 & 9 & 1 & 0 & 0.79 & 0.00 \\
\hline $21 \mathrm{Apr}$ & 104 & 4 & 0 & 0 & 0.00 & 0.00 \\
\hline $22 \mathrm{Apr}$ & 127 & 6 & 4 & 1 & 3.15 & 16.67 \\
\hline $23 \mathrm{Apr}$ & 153 & 7 & 1 & 0 & 0.65 & 0.00 \\
\hline $24 \mathrm{Apr}$ & 185 & 20 & 1 & 0 & 0.54 & 0.00 \\
\hline $25 \mathrm{Apr}$ & 187 & 45 & 1 & 1 & 0.53 & 2.22 \\
\hline $26 \mathrm{Apr}$ & 261 & 33 & 1 & 1 & 0.38 & 3.03 \\
\hline $27 \mathrm{Apr}$ & 198 & 64 & 0 & 2 & 0.00 & 3.13 \\
\hline $28 \mathrm{Apr}$ & 188 & 131 & 5 & 5 & 2.66 & 3.82 \\
\hline $29 \mathrm{Apr}$ & 242 & 282 & 3 & 8 & 1.24 & 2.84 \\
\hline $30 \mathrm{Apr}$ & 219 & 307 & 2 & 10 & 0.91 & 3.26 \\
\hline 01 May & 275 & 292 & 4 & 7 & 1.45 & 2.40 \\
\hline 02 May & 229 & 199 & 3 & 7 & 1.31 & 3.52 \\
\hline 03 May & 414 & 200 & 8 & 3 & 1.93 & 1.50 \\
\hline 04 May & 349 & 358 & 1 & 10 & 0.29 & 2.79 \\
\hline 05 May & 481 & 645 & 6 & 8 & 1.25 & 1.24 \\
\hline 06 May & 617 & 1328 & 5 & 32 & 0.81 & 2.41 \\
\hline 07 May & 657 & 1018 & 9 & 30 & 1.37 & 2.95 \\
\hline 08 May & 736 & 1015 & 8 & 19 & 1.09 & 1.87 \\
\hline 09 May & 1025 & 1555 & 20 & 72 & 1.95 & 4.63 \\
\hline 10 May & 844 & 1230 & 19 & 73 & 2.25 & 5.93 \\
\hline 11 May & 1038 & 2109 & 36 & 140 & 3.47 & 6.64 \\
\hline 12 May & 1019 & 1090 & 26 & 89 & 2.55 & 8.17 \\
\hline 13 Мау & 1734 & 1642 & 56 & 116 & 3.23 & 7.06 \\
\hline 14 May & 1826 & 1507 & 53 & 72 & 2.90 & 4.78 \\
\hline 15 May & 2477 & 1249 & 158 & 49 & 6.38 & 3.92 \\
\hline 16 May & 2443 & 1101 & 104 & 37 & 4.26 & 3.36 \\
\hline 17 Мау & 2511 & 1023 & 91 & 49 & 3.62 & 4.79 \\
\hline 18 May & 2160 & 902 & 25 & 16 & 1.16 & 1.77 \\
\hline 19 May & 2313 & 707 & 14 & 6 & 0.61 & 0.85 \\
\hline 20 May & 1006 & 552 & 15 & 8 & 1.49 & 1.45 \\
\hline 21 May & 900 & 575 & 10 & 5 & 1.11 & 0.87 \\
\hline 22 May & 782 & 597 & 7 & 5 & 0.90 & 0.84 \\
\hline 23 May & 513 & 637 & 12 & 4 & 2.34 & 0.63 \\
\hline 24 May & 1341 & 693 & 26 & 5 & 1.94 & 0.72 \\
\hline 25 May & 1806 & 764 & 5 & 1 & 0.28 & 0.13 \\
\hline 26 May & 1447 & 561 & 28 & 6 & 1.94 & 1.07 \\
\hline 27 May & 1469 & 545 & 24 & 2 & 1.63 & 0.37 \\
\hline 28 May & 669 & 516 & 10 & 14 & 1.49 & 2.71 \\
\hline 29 May & 326 & 231 & 0 & 0 & 0.00 & 0.00 \\
\hline 30 May & 560 & 259 & 5 & 2 & 0.89 & 0.77 \\
\hline
\end{tabular}


Appendix Table 5. Continued.

\begin{tabular}{|c|c|c|c|c|c|c|}
\hline \multirow{2}{*}{$\begin{array}{l}\text { Detection date } \\
\text { at } \\
\text { Bonneville Dam }\end{array}$} & \multicolumn{2}{|c|}{ Bonneville Dam detections } & \multicolumn{4}{|c|}{ Jones Beach detections } \\
\hline & $\begin{array}{l}\text { Chinook } \\
\text { salmon (n) }\end{array}$ & $\begin{array}{l}\text { Steelhead } \\
\text { (n) }\end{array}$ & $\begin{array}{c}\text { Chinook } \\
\text { salmon (n) }\end{array}$ & $\begin{array}{l}\text { Steelhead } \\
\text { (n) }\end{array}$ & $\begin{array}{c}\text { Chinook } \\
\text { salmon (\%) }\end{array}$ & $\begin{array}{l}\text { Steelhead } \\
\text { (\%) }\end{array}$ \\
\hline 31 May & 304 & 139 & 3 & 3 & 0.99 & 2.16 \\
\hline 01 Jun & 110 & 119 & 0 & 4 & 0.00 & 3.36 \\
\hline 02 Jun & 108 & 65 & 2 & 0 & 1.85 & 0.00 \\
\hline 03 Jun & 100 & 77 & 7 & 2 & 7.00 & 2.60 \\
\hline 04 Jun & 121 & 179 & 1 & 5 & 0.83 & 2.79 \\
\hline 05 Jun & 95 & 121 & 0 & 3 & 0.00 & 2.48 \\
\hline 06 Jun & 97 & 136 & 2 & 7 & 2.06 & 5.15 \\
\hline 07 Jun & 149 & 109 & 2 & 0 & 1.34 & 0.00 \\
\hline 08 Jun & 255 & 76 & 0 & 1 & 0.00 & 1.32 \\
\hline 09 Jun & 185 & 116 & 5 & 5 & 2.70 & 4.31 \\
\hline 10 Jun & 197 & 106 & 7 & 6 & 3.55 & 5.66 \\
\hline 11 Jun & 146 & 45 & 3 & 1 & 2.05 & 2.22 \\
\hline 12 Jun & 110 & 32 & 2 & 2 & 1.82 & 6.25 \\
\hline 13 Jun & 152 & 43 & 1 & 1 & 0.66 & 2.33 \\
\hline 14 Jun & 193 & 58 & 6 & 1 & 3.11 & 1.72 \\
\hline 15 Jun & 190 & 64 & 0 & 1 & 0.00 & 1.56 \\
\hline 16 Jun & 206 & 45 & 2 & 1 & 0.97 & 2.22 \\
\hline 17 Jun & 245 & 27 & 3 & 0 & 1.22 & 0.00 \\
\hline 18 Jun & 273 & 40 & 0 & 0 & 0.00 & 0.00 \\
\hline 19 Jun & 282 & 42 & 2 & 1 & 0.71 & 2.38 \\
\hline 20 Jun & 276 & 32 & 0 & 1 & 0.00 & 3.13 \\
\hline 21 Jun & 236 & 37 & 0 & 0 & 0.00 & 0.00 \\
\hline 22 Jun & 169 & 31 & 1 & 1 & 0.59 & 3.23 \\
\hline 23 Jun & 267 & 38 & 2 & 1 & 0.75 & 2.63 \\
\hline 24 Jun & 691 & 23 & 7 & 0 & 1.01 & 0.00 \\
\hline 25 Jun & 1018 & 37 & 12 & 4 & 1.18 & 10.81 \\
\hline 26 Jun & 1092 & 32 & 5 & 0 & 0.46 & 0.00 \\
\hline 27 Jun & 939 & 11 & 0 & 0 & 0.00 & 0.00 \\
\hline 28 Jun & 948 & 19 & 7 & 0 & 0.74 & 0.00 \\
\hline 29 Jun & 512 & 10 & 5 & 0 & 0.98 & 0.00 \\
\hline 30 Jun & 460 & 19 & 4 & 0 & 0.87 & 0.00 \\
\hline $01 \mathrm{Jul}$ & 499 & 19 & 0 & 1 & 0.00 & 5.26 \\
\hline $02 \mathrm{Jul}$ & 597 & 8 & 0 & 0 & 0.00 & 0.00 \\
\hline 03 Jul & 449 & 20 & 0 & 0 & 0.00 & 0.00 \\
\hline $04 \mathrm{Jul}$ & 378 & 4 & 1 & 0 & 0.26 & 0.00 \\
\hline $05 \mathrm{Jul}$ & 391 & 8 & 7 & 0 & 1.79 & 0.00 \\
\hline $06 \mathrm{Jul}$ & 374 & 2 & 6 & 0 & 1.60 & 0.00 \\
\hline $07 \mathrm{Jul}$ & 534 & 8 & 4 & 0 & 0.75 & 0.00 \\
\hline $08 \mathrm{Jul}$ & 565 & 5 & 1 & 0 & 0.18 & 0.00 \\
\hline $09 \mathrm{Jul}$ & 774 & 2 & 13 & 0 & 1.68 & 0.00 \\
\hline $10 \mathrm{Jul}$ & 1026 & 4 & 17 & 0 & 1.66 & 0.00 \\
\hline $11 \mathrm{Jul}$ & 905 & 5 & 0 & 0 & 0.00 & 0.00 \\
\hline $12 \mathrm{Jul}$ & 812 & 0 & 10 & -- & 1.23 & -- \\
\hline $13 \mathrm{Jul}$ & 597 & 2 & 7 & 0 & 1.17 & 0.00 \\
\hline 14 Jul & 566 & 4 & 7 & 0 & 1.24 & 0.00 \\
\hline
\end{tabular}


Appendix Table 5. Continued.

\begin{tabular}{|c|c|c|c|c|c|c|}
\hline \multirow{2}{*}{$\begin{array}{l}\text { Detection date } \\
\text { at } \\
\text { Bonneville Dam }\end{array}$} & \multicolumn{2}{|c|}{ Bonneville Dam detections } & \multicolumn{4}{|c|}{ Jones Beach detections } \\
\hline & $\begin{array}{c}\text { Chinook } \\
\text { salmon (n) }\end{array}$ & $\begin{array}{l}\text { Steelhead } \\
\text { (n) }\end{array}$ & $\begin{array}{c}\text { Chinook } \\
\text { salmon (n) }\end{array}$ & $\begin{array}{l}\text { Steelhead } \\
\text { (n) }\end{array}$ & $\begin{array}{c}\text { Chinook } \\
\text { salmon (\%) }\end{array}$ & $\begin{array}{c}\text { Steelhead } \\
(\%)\end{array}$ \\
\hline $15 \mathrm{Jul}$ & 849 & 1 & 1 & 0 & 0.12 & 0.00 \\
\hline $16 \mathrm{Jul}$ & 677 & 2 & 5 & 0 & 0.74 & 0.00 \\
\hline $17 \mathrm{Jul}$ & 634 & 1 & 10 & 0 & 1.58 & 0.00 \\
\hline $18 \mathrm{Jul}$ & 628 & 2 & 0 & 0 & 0.00 & 0.00 \\
\hline $19 \mathrm{Jul}$ & 482 & 0 & 4 & -- & 0.83 & -- \\
\hline $20 \mathrm{Jul}$ & 448 & 0 & 5 & -- & 1.12 & -- \\
\hline $21 \mathrm{Jul}$ & 499 & 1 & 7 & 0 & 1.40 & 0.00 \\
\hline $22 \mathrm{Jul}$ & 342 & 1 & 1 & 0 & 0.29 & 0.00 \\
\hline $23 \mathrm{Jul}$ & 315 & 1 & 7 & 0 & 2.22 & 0.00 \\
\hline $24 \mathrm{Jul}$ & 289 & 0 & 9 & -- & 3.11 & -- \\
\hline $25 \mathrm{Jul}$ & 351 & 2 & 5 & 0 & 1.42 & 0.00 \\
\hline $26 \mathrm{Jul}$ & 249 & 0 & 3 & -- & 1.20 & -- \\
\hline $27 \mathrm{Jul}$ & 231 & 0 & 4 & -- & 1.73 & -- \\
\hline $28 \mathrm{Jul}$ & 231 & 0 & 0 & -- & 0.00 & -- \\
\hline $29 \mathrm{Jul}$ & 141 & 1 & 3 & 0 & 2.13 & 0.00 \\
\hline $30 \mathrm{Jul}$ & 107 & 0 & 4 & -- & 3.74 & -- \\
\hline $31 \mathrm{Jul}$ & 163 & 0 & 1 & -- & 0.61 & -- \\
\hline 01 Aug & 126 & 1 & 0 & 0 & 0.00 & 0.00 \\
\hline 02 Aug & 47 & 0 & 0 & -- & 0.00 & -- \\
\hline 03 Aug & 51 & 1 & 1 & 0 & 1.96 & 0.00 \\
\hline 04 Aug & 32 & 0 & 1 & -- & 3.13 & -- \\
\hline 05 Aug & 44 & 0 & 0 & -- & 0.00 & -- \\
\hline 06 Aug & 40 & 0 & 0 & -- & 0.00 & -- \\
\hline 07 Aug & 33 & 1 & 0 & 0 & 0.00 & 0.00 \\
\hline 08 Aug & 28 & 0 & 0 & -- & 0.00 & -- \\
\hline 09 Aug & 16 & 0 & 1 & -- & 6.25 & -- \\
\hline 10 Aug & 14 & 0 & 0 & -- & 0.00 & -- \\
\hline 11 Aug & 31 & 0 & 0 & -- & 0.00 & -- \\
\hline 12 Aug & 37 & 0 & 1 & -- & 2.70 & -- \\
\hline 13 Aug & 30 & 0 & 0 & -- & 0.00 & -- \\
\hline 14 Aug & 14 & 0 & 0 & -- & 0.00 & -- \\
\hline 15 Aug & 28 & 0 & 0 & -- & 0.00 & -- \\
\hline 16 Aug & 21 & 0 & 0 & -- & 0.00 & -- \\
\hline 17 Aug & 16 & 0 & 0 & -- & 0.00 & -- \\
\hline 18 Aug & 25 & 0 & 0 & -- & 0.00 & -- \\
\hline 19 Aug & 17 & 0 & 0 & -- & 0.00 & -- \\
\hline 20 Aug & 7 & 0 & 0 & -- & 0.00 & -- \\
\hline 29 Sep-30 Oct & 148 & 8 & 3 & 0 & 2.03 & 0.00 \\
\hline Totals & 63,361 & 28,123 & 1,052 & 967 & 1.66 & 3.44 \\
\hline
\end{tabular}

